\title{
THE SUPERVISORY JURISDICTION OF THE Alberta UTILITIES COMMISSION OVER MUNiCIPALLY OWNED UTILITIES
}

\author{
Nigel BANKes AND DANA POSCENTE*
}

\begin{abstract}
The primary approach in Alberta has been that the distribution of utility services delivered by investor-owned utilities are subject to full economic regulation by the Alberta Utilities Commission, whereas if public utility services are delivered by municipalities it has been recognized that the services should be principally regulated by the municipal council rather than the Commission. Affording the municipal council, or its equivalent, regulatory jurisdiction over municipally owned utilities involves a more politically responsive form of regulation. The role of the Commission in this context is limited. The Commission has exercised narrow jurisdiction to ensure that rates established for municipally owned utilities are internally and externally consistent, and to ensure that such rates are not unreasonably discriminatory.
\end{abstract}

\section{TABLE OF CONTENTS}

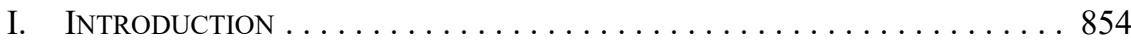

II. UtILITY SERVICES IN ALBERTA AND THE

EVOLUTION OF ENERGY MARKETS . . . . . . . . . . . . . . . . . . . 855

A. Evolution of ENERGy Markets $\ldots \ldots \ldots \ldots \ldots \ldots \ldots 68 \ldots \ldots$

B. Provision of Utility Services Within Municipalities . . . . . 857

C. FRANCHISE AGREEMENTS . . . . . . . . . . . . . . . . . . . . . 859

D. Regulation Where Distribution Utility SERVICE IS

PROVIDED By AN INVESTOR-OWNED UTILITY . . . . . . . . . . . 862

E. REGUlation Where Distribution

UTILITY SERVICE IS PROVIDED BY A

MuniCIPALITY OR A SUBSIDIARY OF A MunicIPALITY . . . . . . . 863

III. The Alberta Utilities COMMission's APPELlate JuRISDiction . . . 864

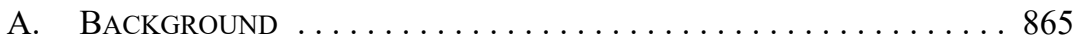

B. ELEMENTS OF THE COMMISSION'S JURISDICTION

TO CONSIDER AN APPEAL . . . . . . . . . . . . . . . . . 867

C. Grounds of APPEAL . . . . . . . . . . . . . . . . . . . 874

D. REMEDiEs AVAilABLE TO THE

Alberta Utilities COMMission When OnE

OR MORE GROUNDS FOR APPEAL ARE SATISFIED . . . . . . . . . 881

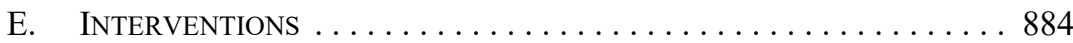

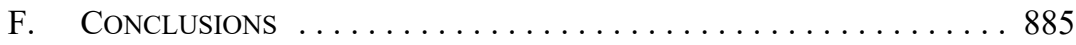

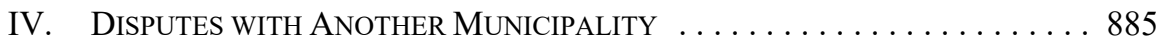

A. Edmonton Water Rates Case No. $1 \ldots \ldots \ldots \ldots \ldots$. . . . 886

B. EdMonton WATER Rates CASE No. $2 \ldots \ldots \ldots \ldots 88$

C. Edmonton Water Rates CASE No. $3 \ldots \ldots \ldots$. . . . . . . 889

D. The Morinville Regional Water Line Decision . . . . . . . 890

Nigel Bankes is a Professor of Law, Faculty of Law, University of Calgary. Dana Poscente, Faculty of Law, University of Calgary is a JD candidate (2021). The authors would like to thank Kristjana Kellgren and one of the Alberta Law Review's anonymous reviewers for comments on earlier drafts of this article. 


\section{E. Natural Gas Dispute Between the Town of RedClifF AND THE City OF MEDICINE HAT . . . . . . . . . . . . . . . . . . . . . 893 \\ F. CONCLUSIONS With RESPECT to SECTION 44 Disputes . . . . . . . 896 \\ V. Overall CONCLUSIONS $\ldots \ldots \ldots \ldots \ldots \ldots \ldots \ldots$}

\section{INTRODUCTION}

This article examines the supervisory jurisdiction of the Alberta Utilities Commission (AUC or Commission) over the delivery of public utility services by municipally owned utilities in Alberta. "Public utility services" are those basic goods and services that we consider essential to live a comfortable and secure life and include electricity, water (both drinking water and waste water or sewage services), and natural gas. ${ }^{2}$ These goods and services are typically delivered through linear infrastructure, and as such are often treated as a natural monopoly. In other words, the network services that they provide are most efficiently delivered by a single carrier (water line, distribution line, and so on) rather than through competing lines of infrastructure. ${ }^{3}$ Since they are treated as monopolies, they are frequently subject to economic regulation. ${ }^{4}$

This article deals with the question of who regulates these public utility services when a municipal government elects to deliver these services itself or through a subsidiary. The general approach in Alberta over the last 50 years has been that the distribution and transmission functions of utility services delivered by investor-owned utilities are, and should be, subject to full economic regulation by the AUC (or its predecessors the Public Utilities Board (PUB) and the Energy and Utilities Board (EUB)). If these public utility services are delivered by municipalities, the principal regulator should be the municipal council, or equivalent, rather than the AUC - that is to say a more politically responsive form of regulation. ${ }^{5}$ In this context, the role of the Commission is a limited supervisory role based on a narrow appeal jurisdiction. There is an exception in one scenario where the legislation affords the Commission a more intrusive supervisory role. This is the case in which a municipally owned utility delivers services within the boundaries of another municipality

The AUC is established by the Alberta Utilities Commission Act, SA 2007, c A-37.2.The AUC maintains an excellent website online: $<$ www.auc.ab.ca/Pages/default.aspx $>$.

Public utility functions are more formally defined in the Municipal Government Act, RSA 2000, c M-26, s 1(1)(y) [MGA]; and in Alberta's three utility statutes: Public Utilities Act, RSA 2000, c P-45, s 1(i) [PUA]; Gas Utilities Act, RSA 2000, c G-5, s 1(1)(g) (defining "gas utility")[GUA]; Electric Utilities Act, SA 2003, c E-5.1, s 1(1)(o) (defining "electric utility") [EUA]. See also Macdonald Communities Limited v Alberta Utilities Commission, 2019 ABCA 353 [Macdonald Communities] noting that "public utility" is more broadly defined for the purposes of section 112 of the PUA which deals with the Commission's jurisdiction to review the rates of regional service commissions. In such a case, the definition includes sewerage and waste management systems as is the case under the MGA. a general discussion of natural monopolies and the case for regulation, see especially ch 1, "Typical Justifications for Regulation").

$4 \quad$ Ibid. See also Central Alberta Rural Electrification Association Limited Application for a Declaration under the Hydro and Electric Energy Act (4 July 2012), 2012-181 at para 101, online: AUC < www.auc. ab.ca/regulatory_documents/ProceedingDocuments/2012/2012-181.pdf $>$ [AUC Decision 2012-181]: "The Commission recognizes that the fundamental economic rationale for regulating electrical distribution companies is that there is an assumption that distribution service is a natural monopoly. As such, it would not be economically efficient for there to be competition and duplication of these services" [citation omitted].

5 See discussion in Town of Redcliff Dispute with City of Medicine Hat Regarding Gas Supply Rates (21 May 2010), 2010-222, online: AUC <www.auc.ab.ca/regulatory documents/ProceedingDocuments/ 2010/2010-222.pdf> [AUC Decision 2010-222]; leave to appeal of a preliminary ruling by the AUC denied in Redcliff (Town) v Medicine Hat (City), 2010 ABCA 11. 
(the host municipality). In this category of cases, the host municipality is disempowered (since it has no role in the political process of the supplying municipality). The Alberta government has responded to this scenario by affording the Commission and its predecessors a much broader appeal jurisdiction over the terms of service, although it still falls short of full prior approval rate-making.

This article is principally based on an analysis of the decisions of the AUC and its predecessors, and the relevant legislation. The first section provides background on the provision of utility services in Alberta and the evolution of energy markets in the province. The second section examines the AUC's appeal jurisdiction in relation to utility services delivered by a municipality. The final section describes the AUC's more extensive appeal jurisdiction in the scenario in which a municipally owned utility delivers services within the boundaries of another municipality

\section{UTILITy SERVICES IN Alberta AND THE EVOLUTION OF ENERGY MARKETS}

Most provincial governments in Canada have chosen to provide some utility services (especially electricity) through vertically integrated Crown corporations such as BC Hydro, SaskPower, Manitoba Hydro, Hydro-Québec and, historically, Ontario Hydro. By contrast, Alberta has consistently favoured the investor-owned utility model, subject to economic regulation by a succession of regulators including the AUC. ${ }^{6}$ This has largely been the case in both the natural gas and electricity sectors, ${ }^{7}$ although in each sector local distribution activities might be undertaken by local governments ${ }^{8}$ or by rural electrification associations (REAs), ${ }^{9}$ and natural gas co-operatives. ${ }^{10}$ Water and waste-water services have typically been

6 For some discussion of provincial Crown energy corporations see HV Nelles, The Politics of Development: Forests, Mines \& Hydro-Electric Power in Ontario, 1849-1941, 2nd ed (Montreal: McGill-Queen's University Press, 2005); Ronald Daniels, ed, Ontario Hydro at the Millenium: Has Monopoly's Moment Passed? (Montreal: McGill-Queen's University Press, 1996).

7 That said, Edmonton did adopt a vertically integrated approach to the generation and supply of electricity through a company then known as Edmonton Power. See Capital Power, "Corporate History," online: <www.capitalpower.com/who-we-are/corporate-history/>. Medicine Hat began generating power for city purposes in 1910 and continues to do so today. See City of Medicine Hat, "Electric Generation," online: <www.medicinehat.ca/government/departments/electric-generation>.

8 For example, in the years prior to the introduction of the wholesale electricity market, ENMAX, Calgary's city owned utility, provided electricity distribution and retail functions in Calgary using power purchased at regulated wholesale rates from TransAlta. See ENMAX, "The ENMAX Group of Companies and The City of Calgary," online: <www.enmax.com/about-us/our-companies/history>.

9 For discussion of the history, role, and status of REAs, see AUC Decision 2012-181, supra note 4; FortisAlberta Inc Application for Orders Confirming Boundaries of FortisAlberta Inc Exclusive Municipal Franchise Areas (16 July 2018), 22164-D01-2018, online: AUC <www.auc.ab.ca/ regulatory_docu ments/ProceedingDocuments/2018/22164-D01-2018.pdf $>$ [AUC Decision 22164-D012018]; Alberta Electric Distribution System-Connected Generation Inquiry Final Report (29 December 2017 ) proceeding 22534 at para 89, online: AUC $<$ www.auc.ab.ca/Shared\%20Documents/Distribution GenerationReport.pdf $>$.

10 For natural gas cooperatives, see Gas Distribution Act, RSA 2000, c G-3 [GDA]; Chief Mountain Gas Co-op Ltd and County of Cardston Municipal Franchise Agreement (31 July 2008), 2008-065, online: AUC < www.auc.ab.ca/regulatory_documents/ProceedingDocuments/2008/2008-065.pdf $>$ [AUC Decision 2008-065]; East Prairie Métis Settlement and Prairie River Gas Co-op Natural Gas Billing Dispute (27 December 2012) 2012-363, online: AUC < www.auc.ab.ca/regulatory_documents/Proceed ingDocuments/2012/2012-363.pdf > [AUC Decision 2012-363]; Evergreen Gas Co-op Ltd Request for Evergreen Gas Co-op Ltd to Remove Utility Rights-of-Way(6 September 2013), 2013-333, online: AUC $<$ www.auc.ab.ca/regulatory_documents/ProceedingDocuments/2013/2013-333.pdf>. 
provided in Alberta through local and regional utilities through varying combinations of investor-owned and municipally owned utility services. ${ }^{11}$

\section{A. EVOLUTiOn OF ENERgY MARKETS}

While utility services that involve significant linear infrastructure are typically subject to economic regulation, it is possible in some circumstances to unbundle a utility service and separate out the lines element of the service (the natural monopoly) from the commodity portion of the service (for example, the natural gas or electricity) carried on the lines. Unbundling allows the price of the commodity to be established by market forces, leaving only the lines part of the business subject to economic regulation.

For example, in the case of electricity, the wholesale price of electricity in Alberta has been set through the power pool since $1996 .{ }^{12}$ The power pool functions as a market. The Alberta Electric System Operator ranks the bids of generation according to their economic merit. ${ }^{13}$ The bid price of the last unit dispatched averaged over an hour sets the system marginal price paid to all generation that is dispatched to meet market demand. There is also a market at the retail level. Retailers may offer different contractual packages of services for the retail commodity, addressing matters such as contract duration, price, and source of energy (for example, green or renewable energy). Not all consumers, however, are obliged to participate in the retail market and contract for power. The $E U A^{14}$ and the associated Regulated Rate Option Regulation ${ }^{15}$ provide that eligible customers may elect instead to avail themselves of the regulated rate tariff. ${ }^{16}$ An eligible customer who does not enroll with a retailer is deemed to have elected to purchase electricity service under the regulated rate tariff. ${ }^{17}$ It is the responsibility of the owner of the electric distribution system to prepare a regulated rate tariff for the approval of its "regulatory authority" (such as the AUC for investor-owned utilities, the municipal council where the distribution utility is owned by a municipality or an affiliate thereof, or the Board of Directors of an REA). ${ }^{18}$ The owner of the

11 For example, there are a number of investor-owned water utilities operating in Alberta that are subject to full economic regulation by the AUC. See AUC, "Water Decisions for Reference," online: $<$ www.auc.ab.ca/regulatory_documents/Pages/water-decision-index.aspx $>$. The AUC does not regulate investor-owned utilities that provide sewage services: see Macdonald Communities, supra note 2. Prior to 1996, the price of electricity was determined on a cost of service basis as regulated by the PUB. For some of the background see Alberta Power Limited v Alberta Public Utilities Board, 1990 ABCA 33.

13 EUA, supra note 2, s 18; Alberta Electric System Operator, "Determining the Wholesale Price for Electricity," online:<www. aeso.ca/download/listedfiles/Determining-the-Wholesale-Market-Price-forElectricity.pdf>.

$14 \quad$ EUA, ibid, s 103(1)

15 Regulated Rate Option Regulation, Alta Reg 262/2005 [RRO Regulation]. For the background to the RRO Regulation, see Retail Market Review Committee, "Power for the People: Report and Recommendations for the Minister of Energy" (2012), online: Government of Alberta < open.alberta.ca/ dataset/c4b279c0-63a5-4a87-87ca-cbd5e4152794/resource/4246f8f0-2572-413f-8cec-d9ec28452fdd/ download/rmrcreport.pdf $>$. See also Direct Energy Regulated Services, ENMAX Energy Corporation and EPCOR Energy Alberta GP Inc Regulated Rate Tariff and Energy Price Setting Plans - Generic Proceeding: Part B - Final Decision (10 March 2015), 2941-D01-2015 at paras 44-64, online: AUC $<$ www.auc.ab.ca/regulatory_documents/ProceedingDocuments/2015/2941-D01-2015.pdf>.

RRO Regulation, ibid, s 1(d) defines an "eligible customer" as a "rate classification customer" and any other customer whose forecast annual consumption of electric energy is less than $250 \mathrm{MWh}$ at a particular site. A "rate classification customer" (s 1(h)) is: "(i) a residential rate classification customer, (ii) a farm rate classification customer, or (iii) an irrigation rate classification customer as defined in a regulated rate tariff."

17 EUA, supra note 2, s 103(9).

18 RRO Regulation, supra note $15, \mathrm{~s} 1(\mathrm{k})$. 
distribution utility is principally responsible for acting as the regulated rate provider ${ }^{19}$ but may make arrangements with another person to perform this or other functions of an owner. ${ }^{20}$ The RRO Regulation establishes the parameters for such a tariff, which must be "just, reasonable and electricity market based." ${ }^{, 21}$

The growth of the retail electricity market was compromised in 2017 with the introduction by the Notley government of An Act to Cap Regulated Electricity Rates. ${ }^{22}$ The ACRER proposed to cap electricity rates for regulated rate customers at 6.8 cents per kilowatt hour (kWh) between June 2017 and May 2021. ${ }^{23}$ The ACRER however was repealed by the Kenney government effective 30 November $2019 .^{24}$

Unbundling has also occurred in the natural gas sector with the separation of the retail and distribution functions. Consumers are free to deal with a retailer of their choice. Although, much as in the electricity sector, retail customers may elect or may be deemed to have elected to take service from the default provider. ${ }^{25}$ There is no prospect of unbundling for other utility services routinely offered by municipalities, such as potable water or sewage.

\section{B. Provision OF Utility Services Within Municipalities}

A municipality can elect to provide a utility service itself (or through a subsidiary), or allow one or more investor-owned utilities or another municipality to provide that service within its boundaries. Section 7 of the MGA provides that a council of a municipality "may pass bylaws for municipal purposes" in relation to a number of matters including "public utilities." 26 The MGA defines "public utility" as "a system or works used to provide" a number of listed services "for public consumption, benefit, convenience or use" including water or steam, sewage disposal, fuel, electric power, and heat. ${ }^{27}$ Section 8 of the MGA goes on to provide that a bylaw under one of the heads of section 7 may regulate or prohibit activities and may provide for a scheme of licences, permits and approvals. Section 9 recognizes that the general jurisdiction of a municipality to pass bylaws "is stated in general terms" in order to:

(a) give broad authority to councils and to respect their right to govern municipalities in whatever way the councils consider appropriate, within the jurisdiction given to them under this or any other enactment, and

(b) enhance the ability of councils to respond to present and future issues in their municipalities. ${ }^{28}$

EUA, supra note 2, s 105(1)(i).

Ibid, s 104. For example, Direct Energy is the regulated rate provider in ATCO Electric's Service Area: see Direct Energy Regulated Services v Alberta Utilities Commission, 2016 ABCA 156 at para 2. RRO Regulation, supra note $15, \mathrm{~s} 4(1)$.

SA 2017, c C-2.3 as it appeared on 7 June 2017 [ACRER]. See also Rate Cap (Board or Council Approved Regulated Rate Tariffs) Regulation, Alta Reg 139/2017; Rate Cap (City of Medicine Hat) Regulation, Alta Reg 256/2017; Rate Cap (Commission Approved Regulated Rate Tariffs) Regulation, Alta Reg 138/2017.

ACRER, ibid, s 2(1).

Bill 21, Ensuring Fiscal Sustainability Act, 2019, 1st Sess, 30th Leg, Alberta, 2019 (assented to 5 December 2019), SA 2019, c 18.

Default Gas Supply Regulation, Alta Reg 184/2003; GUA, supra note 2, s 28.1. The website of the Utilities Consumer Advocate provides a listing of distributors and retailers as well as a cost comparison tool, Utilities Consumer Advocate, "Retailers and Distributors," online: <www.ucahelps.alberta.ca/ retailers.aspx $>$.

MGA, supra note $2, \mathrm{~s} 7(\mathrm{~g})$.

Ibid, s 1(1)(y). The definition goes on to provide that it includes the commodity itself.

Ibid, s. 9. 
Both the courts and the Commission have commented on these sections of the MGA. In United Taxi Drivers' Fellowship of Southern Alberta v. Calgary (City), Justice Bastarache noted that there have been developments in both judicial interpretation and drafting of municipal government legislation. ${ }^{29}$ With respect to the interpretive approach, Justice Bastarache recognized that the courts now embrace a "broad and purposive approach to the interpretation of municipal powers." ${ }^{30}$ At the same time, "the modern method of drafting municipal legislation [has] ... moved away from the practice of granting municipalities specific powers in particular subject areas, choosing instead to confer them broad authority over generally defined matters." ${ }^{31}$ Alberta's legislation is consistent with this trend. ${ }^{32}$ The Commission in turn has commented as follows with respect to the drafting and interpretation of municipal government legislation:

\begin{abstract}
The Commission is of the view that in enacting the Municipal Government Act, the legislature intended to confer to municipal councils broad authority and as much latitude as possible in dealing with local matters. Section 7 gives a municipal council broad general jurisdiction to pass bylaws, including bylaws with respect to municipal public utilities. Section 8 enhances the broad powers conferred by Section 7 , which authorizes a municipality "without restricting Section 7" to exercise the broad powers described in Section 7 in certain, specific ways. The Commission's interpretation is further reinforced by the language in Section 9, which confirms that jurisdiction over municipal-related matters rests with the municipality in the broadest terms. ${ }^{33}$
\end{abstract}

Division 3 of Part 3 of the MGA deals with the more specific powers of municipalities with respect to public utilities. ${ }^{34}$ There are three important points to be made about this Division of the MGA for present purposes.

First, section 33 expressly allows a municipality that provides a municipal utility service to establish a de jure monopoly; it may make a bylaw prohibiting any other person from "providing the same or a similar type of utility service in all or part of the municipality." 35 Section 33.1 makes it clear that this de jure monopoly cannot extend to the retail function under the terms of the EUA since that would be inconsistent with the existence of a retail

2004 SCC 19 at para 6.

Ibid.

Ibid.

Ibid at para 7. See also Kozak v Lacombe (County) 2017 ABCA 351 [Kozak], concluding that a municipality has the authority to enact a bylaw requiring an owner to take a public utility service even though there is no specific provision in the MGA expressly so providing. The Court also noted at para 71 that:

The public policy goals of the $M G A$ support a broad and purposive interpretation of the $M G A$. The $M G A$ contains a complex web of rules for orderly governance by democratically elected municipal councils in the interest of their citizens. The purposes of a municipality are as set out in $\mathrm{s} 3$ of the $M G A$ : to provide good government; to provide services, facilities and other things that, in the opinion of council, are necessary or desirable for the municipality; and ultimately, to develop and maintain safe and viable communities. 22465-D01-2018 at para 30, online: AUC <www.auc.ab.ca/regulatory_documents/Proceeding Documents/2018/22465-D01-2018.pdf> [AUC Decision 22465-D01-2018]. See also AUC Decision 22164-D01-2018, supra note 9, especially at paras 105-12. EPCOR Water Services Inc Appeal of Water Utility Charges by Katelyn Garlough (14 June 2018), 22896-D01-2018 at para 24, online: AUC $<$ www.auc.ab.ca/regulatory_documents/Proceeding Documents/2018/22896-D01-2018.pdf> [AUC Decision 22896-D01-2018]. 
market in electricity and the concomitant right of a customer to choose its own retail arrangements. ${ }^{36}$

Second, while the broad power to make bylaws with respect to public utility service confirms that the municipal council may establish rates, terms, and conditions for utility service, ${ }^{37}$ section 43 creates a limited appeal right to the AUC in respect of matters pertaining to service charges, rates, and tolls relating to municipal utility service. Section 44 affords the AUC a broader supervisory jurisdiction over complaints between municipalities with respect to the supply of utility services. Together, sections 43 and 44 create the complaint jurisdiction of the Commission over municipal utilities. We explore the Commission's jurisdiction under these sections of the MGA in Parts III and IV of this article.

Third, where a municipality elects not to provide a utility service itself, section 45 of the MGA confirms that it may enter into a franchise agreement with another party, granting the other party the right, "exclusive or otherwise," to provide that utility service. ${ }^{38}$ While section 45 does not expressly provide that a municipality may charge a franchise fee in return for granting such a right, the EUB, the predecessor of the Commission, concluded that this power might be implied. ${ }^{39}$ A municipality may impose a linear tax on distribution facilities as well as a franchise fee. ${ }^{40}$

The next section explores some of the rules pertaining to franchise agreements.

\section{Franchise Agreements}

A franchise agreement is an agreement whereby a municipality grants another party the right to provide a utility service within the boundaries of the municipality. ${ }^{41} \mathrm{~A}$ franchise agreement may not have a term longer than 20 years and before any such agreement may be

MGA, ibid, s 33.1 and EUA, supra note 2, s 110: "Subject to this Act and the regulations, a customer has the right to obtain retail electricity services from a retailer."

And in the case of electric distribution utilities, this is confirmed by section 103 of the EUA, ibid.

MGA, supra note 2, s 45(1).

See Alberta Urban Municipalities Association Standard Electric Franchise Agreement with ATCO Electric Ltd and Utilicorp Networks Canada (19 June 2001), 2001-52 at 5, 8, online: EUB <www. auc.ab.ca/regulatory documents/ProceedingDocuments/2001/2001-52.pdf> [EUB Decision 2001-52] referencing QCTV L $\bar{t} d v$ Edmonton (City) (1983), 1 DLR (4th) 116. Furthermore, the EUB was of the view that a franchise fee was not a tax within the meaning of s 360 of the MGA.

40 EUB Decision 2001-52, ibid at 6, referring at 5 to s 353 of the $M G A$

41 The expansion of urban municipalities such as a city or a town to include surrounding rural areas, for example, through an annexation, may lead the holder of the municipal franchise agreement to apply to the AUC under s 29 of the Hydro and Electric Energy Act, RSA 2000, c H-16 for the expansion of its distribution area to coincide with the new municipal boundaries, although the result may be to similarly reduce the distribution area of an REA. The Commission has concluded that such applications will generally be granted on the basis that they are in the public interest. See AUC Decision 22164-D012018, supra note 9 at para 98 . The Commission gave four reasons for its decision to grant FortisAlberta's multiple applications in that case. Granting the alteration:

i. Harmonizes the service areas to reflect the boundaries governed by the MFAs and is consistent with the Commission's previous approval of those agreements.

ii. Best supports the public policy objective of avoiding unnecessary duplication of facilities.

iii. Is most consistent with the legislated purpose of municipalities and REAs.

iv. Best supports or gives effect to the broad public policy goals of the MGA as a whole and the intent of the legislature in establishing and empowering municipalities. As a corollary, it would be contrary to the public interest to deny the municipalities the authority granted under the $M G A$ and to disregard their express intentions. 
entered into, amended, or renewed, it must be advertised and approved by the AUC. ${ }^{42}$ As with section 33.1 (above), section 45.1 of the MGA clarifies that in the case of electricity, such an agreement cannot grant an exclusive right to a person to provide the functions or services of retailers as described in the EUA. Sections 139 to 141 of the EUA provide further guidance with respect to these matters in the context of electric utility services. ${ }^{43}$ Taken together, section 45 of the MGA and sections 139 to 141 of the EUA provide that the Commission may only approve the grant of the right to distribute electricity if: (1) it "determines that the grant is necessary and proper for the public convenience and to properly serve the public interest"; ${ }^{44}$ (2) "the grant does not prevent the Crown from exercising" the right to distribute electricity, ${ }^{45}$ (3) it is satisfied "that the proposed scheme for the distribution of electricity is reasonable and sufficient, having regard to the general circumstances"; ${ }^{46}$ and (4) it is satisfied that "the grant is to the general benefit of the area directly or indirectly affected by it." 47

In approving a grant, the Commission may "impose any conditions as to construction, equipment, maintenance, service or operation that the public convenience and the public interest reasonably require." 48 Special rules apply where a municipality proposes to grant another municipality, or a corporation controlled by that other municipality, the right to distribute electricity within its boundaries. ${ }^{49}$

In assessing franchise agreements, the Commission (and its predecessors) has also referred to other matters that it might consider as part of its public interest mandate: (1) the need to ensure that the terms of the agreement do not compromise the ability of a municipality to properly negotiate future franchise agreements $;{ }^{50}(2)$ the total impact of the different levies that the municipality may impose, including franchise fees under the agreement, as well as linear taxes, in order to ensure that the charges that will be recovered from customers will not be unreasonable, ${ }^{51}$ (3) an assessment to ensure that there will be no inappropriate crosssubsidization between discrete communities within a municipality ${ }^{52}$ or any unreasonable discrimination; ${ }^{53}(4)$ the need to ensure that the terms of the franchise agreement support and

Agreements between a municipality and a regional services commission do not require the approval of the AUC, and an agreement between a municipality and its subsidiary to provide a utility service need not be advertised nor submitted to the AUC for approval: MGA, supra note 2, ss 45(4)-(5); but see ENMAX Power Corporation Tax Agreement with The City of Calgary (7 September 2017), 22756-D012017, online: AUC <www.auc.ab.ca/regulatory_documents/ProceedingDocuments/2017/22756-D012017.pdf $>$.

43 There are similar provisions in the PUA, supra note 2, ss 106-107 and the GUA, supra note 2, ss 4950.

EUA, supra note 2, s 139(2).

Ibid, s 140(a).

Ibid, s 140(b).

Ibid, s 140 (c).

Ibid, s 139(3).

Ibid, ss 139(4)-(5). In particular, the grant of authority must be approved by regulation.

EUB Decision 2001-52, supra note 39 at 4.

Ibid at 6; AltaGas Utilities Inc Approval of New Standard Natural Gas Distribution System Franchise Agreement Template (20 March 2015), 20069-D01-2015 at para 30, online: AUC <www.auc.ab.ca/ regulatory_documents/ProceedingDocuments/2015/20069-D01-2015.pdf > [AUC Decision 20069-D012015] (approving of a proposal to calculate the franchise fee based on total revenues received from the distribution function and excluding any revenues from commodity charges).

EUB Decision 2001-52, supra note 39 at 11 .

Ibid at 12 and noting that its jurisdiction to avoid undue discrimination comes from the EUA in relation to investor-owned utilities and from section 43 of the MGA in relation to municipally owned utilities. See also Evergreen Gas Co-op Ltd Franchise Agreement with the Town of Drayton Valley (2 May 2019), 24257-D01-2019, online: AUC <www.auc.ab.ca/regulatory documents/ProceedingDocuments/ 
do not detract from the right of municipalities to choose their utility ${ }^{54}(5)$ the need to ensure that the franchise agreement is not inconsistent with any requirements of provincial legislation; ${ }^{55}$ (6) the Commission will be reluctant to approve schemes whereby the utility bears responsibility for relocation costs triggered for municipal purposes since this may lead to inappropriate cross-subsidization, ${ }^{56}$ and (7) "the Commission may consider whether the public is likely to be harmed or placed at a reasonably foreseeable risk of harm if the Commission approves the franchise agreement" ${ }^{\prime 57}$ and in that context will assess whether the proposed franchisee "has sufficient expertise to effectively manage the rate regulatory aspects of operating a ... utility and the financial stability to maintain safe and reliable service." 58

An agreement that is not renewed continues in effect until terminated by either party on six months' notice with the approval of the Commission. ${ }^{59}$ If notice to terminate has been given, the municipality may purchase "the rights, systems and works of the public utility." Where the parties are unable to reach agreement on the purchase price, either party may refer the matter to the Commission, which "must by order fix the terms and price of the purchase and the order is binding on the parties." ${ }^{\prime 61}$ The EUB, the predecessor of the Commission, has stated that the purpose of this section 47 of the $M G A$,

is to provide uniformity in provision of service even when franchise agreements have expired and new agreements have not yet been negotiated and implemented. This in turn allows municipalities and utilities the ability to properly negotiate future franchise agreements without compromising the rights and responsibilities provided in a franchise agreement. ${ }^{62}$

Most applications that come before the Commission for approval of an electricity franchise agreement are based on a standard template. ${ }^{63}$ The most recent version of the electricity template was negotiated between FortisAlberta Inc., ATCO Electric Ltd., and the

2019/24257-D01-2019.pdf> [AUC Decision 24257-D01-2019]. The Commission declined to approve a proposed franchise agreement that proposed that there should be no franchise fee for the first ten years but instituting a franchise fee thereafter but only for new customers. The Commission considered that there was no "reasonable rationale or basis for differential treatment between these two customer groups" (at para 23).

$54 \quad$ AUC Decision 2008-065, supra note 10 at 9

55 AUC Decision 20069-D01-2015, supra note 51 at paras 25-27. The Commission satisfied itself that the proposed standard form agreement was not inconsistent with section 50(1) of the GUA, supra note 2. See also discussion at paras 37-38.

56 EUB Decision 2001-52, supra note 39 at 13-15; Town of Bow Island Review of Proposed Standard Natural Gas Franchise Agreement with ATCO Gas and Pipelines Ltd (9 September 2003), 2003-065 at 6-7, online: EUB < www.auc.ab.ca/regulatory_documents/ProceedingDocuments/2003/2003-065.pdf> [EUB Decision 2003-065].

57 Strathcona County Water Franchise Agreement and Long-Term Water Supply Agreement with Properties of Northern Bear Inc (15 April 2016), 20780-D01-2016 at para 28, online: AUC <www.auc. ab.ca/regulatory documents/ProceedingDocuments/2016/20780-D01-2016.pdf>.

$58 \quad$ Ibid at para 42. The AUC concluded that approval of the proposed franchise to provide water services would not be in the public interest.

$M G A$, supra note 2, s 47(1). According to the AUC, this procedure serves "to ensure that suitable new arrangements are in place" (AUC Decision 2010-222, supra note 5 at para 138).

MGA, ibid, s 47(2).

Ibid, s 47(4).

EUB Decision 2001-52, supra note 39 at 4.

One advantage of using the standard form is that it expedites approval. See AUC, Applications for Municipal Franchise Agreements and Associated Franchise Fee Rate Riders, Rule 029, online: <www. auc.ab.ca/Shared\%20Documents/rules/Rule029.pdf>. 
Alberta Urban Municipalities Association, and was approved by the AUC in $2012 .{ }^{64}$ The EUB, as the predecessor of the AUC, first approved this approach in $2001 .^{65} \mathrm{In}$ its decision at that time, the EUB noted that previous practice had been for each utility to develop its own standard form to use in negotiations with municipalities. ${ }^{66}$ The EUB supported the use of a more universal standard form agreement on the basis that it "could help clarify the rights and responsibilities of both utilities and municipalities with respect to the provision of utility services" and make negotiation of renewals easier. ${ }^{67}$ Such an agreement might be particularly useful for smaller municipalities that lack the necessary resources to review a proposed agreement. The EUB noted that municipalities were not required to use the standard form and that parties should have the option to modify it. ${ }^{68}$

The gas utilities followed suit and the EUB approved a standard form gas contract for both ATCO Gas and Pipelines Ltd. ${ }^{69}$ and AltaGas Ltd. ${ }^{70}$ in 2003. The Commission approved a new standard form in 2015 to be used by both utilities. ${ }^{71}$

In conclusion, within a municipality, the municipal government may elect to provide electricity or natural gas distribution service itself or through a subsidiary, or it may elect to have an investor-owned utility or another municipality provide the distribution service under the terms of a franchise agreement. We now turn to examine the responsibility for regulating distribution service in each of these scenarios.

\section{Regulation Where Distribution UTILITy SERVICE IS PROVIDED BY AN INVESTOR-OWNED UTILITY}

Where the distribution service is provided by an investor-owned utility, the utility will be subject to full economic regulation by the AUC under the terms of the EUA, GUA or PUA as relevant. In the case of the EUA for example, this requires the owner of the utility to prepare a tariff and apply to the AUC for approval of the tariff. ${ }^{72}$ The owner cannot put the tariff into effect without the AUC's approval (that is, prior approval regulation). ${ }^{73}$ The tariff must be just, reasonable, and non-discriminatory, and must provide the owner with a reasonable opportunity to recover its costs and expenses, including a fair return on equity. ${ }^{74}$ Historically, the AUC regulated distribution utilities on a traditional cost of service basis, but over the last number of years it has moved to performance-based regulation (PBR), also

Town of Hinton New Franchise Agreement Template and Franchise Agreement with FortisAlberta Inc (28 September 2012), 2012-255, online: AUC <www.auc.ab.ca/regulatory documents/ProceedingDocu ments/2012/2012-255.pdf>.

EUB Decision 2001-52, supra note 39.

Ibid at 1 .

Ibid at 2 .

Ibid at 3 .

EUB Decision 2003-065, supra note 56.

Town of Bonnyville Review of Proposed Standard Natural Gas Franchise Agreement with AltaGas Utilities Inc (9 September 2003), 2003-067, online: EUB <www.auc.ab.ca/regulatory_documents/ ProceedingDocuments/2003/2003-067.pdf\#search=2003\%2D067>.

AUC Decision 20069-D01-2015, supra note 51.

EUA, supra note 2, s 119(1). See also EUA, s 102(2) requiring the owner of an electric distribution system to apply for approval of its distribution tariff to the AUC where the owner is not a municipality or an REA.

Ibid, s 125 .

Ibid, s 122(1)(a). 
known as I minus X (I-X) regulation. ${ }^{75}$ Under this form of regulation, rates are established initially on the basis of cost of service regulation and then, in subsequent years, adjusted by an inflationary factor (I) as well as an X factor that is intended to represent efficiency gains that the utility can be expected to achieve. To the extent that the utility is able to beat the $\mathrm{X}$ factor (established on the basis of a total factor productivity study), it is entitled to retain the benefit. PBR is significantly more complex in practice than this simple description might suggest, since additional adjustments are also made for other factors such as capital investments and unexpected events. ${ }^{76}$ Nevertheless, the important point for present purposes is that investor-owned distribution utilities are subject to detailed prior approval economic regulation by the AUC - whether based on traditional cost of service principles or PBR.

\section{E. Regulation Where Distribution Utility Service is Provided by a MUNICIPALITY OR A SUBSIDIARY OF A MUNICIPALITY}

The general rule is that where a distribution utility service is provided by a municipality or a subsidiary of a municipality, that service is not subject to prospective economic regulation by the AUC. Instead, it is the municipal council itself that approves the rates for those municipally provided services. The purpose of the general rule "recognizes and acknowledges the autonomy of local government and their prerogatives with respect to the management of their affairs." $" 77$ The ultimate recourse for customers is "through the election process if they are not satisfied with the management of those utilities.", "The general rule is subject to some exceptions.

There is a general exception to the effect that a municipality may, through the adoption of a bylaw approved by Order in Council, agree to bring a utility service under the relevant legislation (such as the GUA, PUA, or EUA). The general rule is established by the definitions in each of the PUA and GUA that define the owner of the respective utility in such a manner so as not to include a municipality that owns a utility unless it has made such a

75 The key decision is Rate Regulation Initiative Distribution Performance-Based Regulation (12 September 2012), 2012-237, online: AUC <www.auc.ab.ca/regulatory_documents/ProceedingDocu ments/2012/2012-237.pdf> [AUC Decision 2012-237]. This decision established the PBR framework for two gas distribution utilities (AltaGas Utilities Inc and ATCO Gas and Pipeines Ltd) and four electric distribution utilities, ATCO Electric Ltd, ENMAX Power Corporation, EPCOR Distribution \& Transmission Inc and FortisAlberta Inc, for the period 2015-2017. In a subsequent decision, Errata to Decision 20414-D01-2016 2018-2022 Performance-Based Regulation Plans for Alberta Electric and Gas Distribution Utilities (6 February 2017), 20414-D01-2016, online: AUC <www.auc.ab.ca/ regulatory_documents/ProceedingDocuments/2016/20414-D01-2016\%20(Errata).pdf $>$ [AUC Decision 20414-D01-2016], the AUC established the parameters of the PBR plan for these six utilities for the 2018-2022 period.

76 These additional adjustments include "an adjustment for certain flow-through costs that should be recovered from, or refunded to, customers directly (a Y factor), and an adjustment to account for the effect of exogenous and material events for which the distribution utility has no other reasonable cost recovery or refund mechanism within the PBR plan (a $\mathrm{Z}$ factor). In addition, the Commission determined that a rate adjustment mechanism to fund certain capital-related costs may be required under the approved PBR plans. This rate adjustment mechanism was referred to in Decision 2012-237 as a 'capital tracker' with the revenue requirement associated with approved amounts to be collected from ratepayers by way of a 'K factor' adjustment to the annual PBR rate-setting formula" (AUC Decision 20414-D012016, ibid at para 20).

77 Application Pursuant to Section 280 of the Municipal Government Act, Municipal District of Sturgeon No 90 (27 September 1979), E79036 at 16, PUB [PUB Decision E79036]. Ibid. 
bylaw. ${ }^{79}$ The EUA provisions are more complex. While the EUA equally provides that a municipality may bring itself under Commission regulation by way of a bylaw approved by Order in Council, ${ }^{80}$ it also provides that an electric utility will be regulated under the EUA where the EUA requires the owner to apply to the Commission for approval of a tariff. ${ }^{81}$ While a municipal utility that owns a distribution system will generally only have to apply to its Council for approval of its tariff, ${ }^{82}$ this is not the case if the municipal utility provides, through an affiliate or otherwise, distribution service outside the service area of the municipality. In such a case, the municipal utility loses its "exemption" and must apply to the Commission for approval of its tariff. ${ }^{83}$ It is for this reason that both ENMAX Power Corporation and EPCOR Distribution Inc. (the electricity subsidiaries of the Cities of Calgary and Edmonton respectively) have been subject to full economic regulation by the AUC since $2004{ }^{84}$ It follows that the municipal exemption under the EUA is narrower than the exemption available under both the PUA and the GUA. A municipally owned water utility, for example, does not come under Commission regulation simply because it provides utility service outside its boundaries. ${ }^{85}$

Finally, even where the municipal council has the authority to establish tariffs and charges for its utility service within its own municipal boundaries, the AUC has a limited jurisdiction to consider complaints in relation to municipally established rates under the terms of section 43 of the MGA. This is the subject of the next part of the article.

\section{The Alberta Utilities Commission's APPEllate JURISDiction}

This part begins by considering the legislative history of the appellate (complaint) jurisdiction of the AUC and its predecessors and then examines the different elements of that jurisdiction.

See e.g. PUA, supra note 2, ss 1(h) (definition of "owner of a public utility"), 111; GUA, supra note 2, ss 1(1)(j) (definition of "owner of a gas utility"), 4(2)-(4).

This follows from EUA, supra note 2, ss 1(1)(o)(v), 138.

Ibid, s 1(1)(o)(iii).

Ibid, s 102(2)(b); REAs see s 102(2)(c).

This follows from a reading of section 102 of the EUA as a whole. Essentially, the owner of a distribution system must apply to the AUC for tariff approval (ibid, s 102(2)(a)) unless it can fit itself within paragraphs (b) (the municipal exception) or (c) (the REA exception). A municipal utility that provides service outside its boundaries cannot bring itself within paragraph (b).

$84 \quad$ See AUC, "Who We Regulate," online: <www.auc.ab.ca/pages/who-we-regulate.aspx>. I am grateful to Lou Cusano and Erica Young for helping me to clarify the source of the AUC's ratemaking jurisdiction over both ENMAX and EPCOR. See also Distribution Tariff Regulation, Alta Reg $162 / 2003$, s 4.

85 It may however come under the AUC's broader complaint jurisdiction under MGA, supra note 2, s 44 as we explore in Part IV of this article. 


\section{A. BACKGROUND}

The appeal jurisdiction of the AUC and its predecessors was first introduced in The Municipal Government Act in $1968 .{ }^{86}$ As originally enacted, section 280 provided that:

Any user of a public utility being aggrieved respecting service charges, rates and tolls made to such user may by application appeal to the Public Utilities Board and the Board, if satisfied that such service charge

(a) does not conform to the public utility rate structure established by the municipality, or

(b) has been improperly imposed, or

(c) is discriminatory,

may make an order varying, adjusting or disallowing the whole or any part of such charge.

The PUB recognized from the outset that this conferral of appellate jurisdiction was quite different from its function as a "rate-setting agency" for investor-owned utilities. ${ }^{87}$ In its view,

the Legislature did not intend the Board to carry out its duties in a manner that would detract from the clear rights of municipalities to fix their own rates... [T] he Legislature intended that the Board's prime function is to correct inequalities in municipal utility rates and charges but not to substitute its opinion of what the rates and charges should be.

As a rate setting agency, the practice of the Board is to hold a rate hearing in which evidence of relevant financial and economic matters are presented by expert witnesses.... In such a hearing all aspects of the effect of fixing utility rates and charges on consumers are discussed and considered at great length. It is only after this procedure has been followed that the Board sets utility rates. This is the practice the Board would follow if the Town of Vulcan passed the appropriate by-law to bring its water and sewer utilities under Board control. However, acting as it must, as a tribunal under Section 280 and not as a regulatory authority the Board has concluded that it should not interfere with municipal utility rates brought before it under the section beyond the point of correcting injustices that have been established by the evidence adduced at the hearing. ${ }^{88}$

The basic structure of this provision is maintained in the current section 43 of the MGA. The most significant amendment over the last five decades was the addition of the clarification in 1994 to the effect that an appeal under this section could "not challenge the and gives ratepayers a new right to appeal utility rates that was not available under the statute which The Municipal Government Act replaced." And to the same effect, Arthur J Leoni and Hazel F Marshall and The Town of Vulcan (24 July 1969), 29426 at 3, PUB [PUB Decision 29426]. 
public utility rate structure itself." 89 As the Commission has noted, this caveat confirms that the "legislature intended to restrict the scope of the Commission's authority under [the appeal provision] to the consideration of individual complaints"; 90 it cannot vary rates for a person that has not filed an appeal and it cannot require a utility to restructure its rate design. Section 43 currently reads as follows:

43(1) A person who uses, receives or pays for a municipal utility service may appeal a service charge, rate or toll made in respect of it to the Alberta Utilities Commission, but may not challenge the public utility rate structure itself.

(2) If the Alberta Utilities Commission is satisfied that the person's service charge, rate or toll

(a) does not conform to the public utility rate structure established by the municipality,

(b) has been improperly imposed, or

(c) is discriminatory,

the Commission may order the charge, rate or toll to be wholly or partly varied, adjusted or disallowed. ${ }^{91}$

Before examining the individual elements of section 43, it is useful both to recall our earlier comments in Part II.B of this article with respect to the judicial approach to the interpretation of the MGA and to consider the Commission's general approach to the interpretation of section 43. A 2018 decision dealing with an appeal with respect to EPCOR Water Services Inc is pertinent. ${ }^{92}$ In that decision, the Commission emphasized that it was important to read section 43 harmoniously with the entire scheme of the MGA, recognizing, as noted above, the modern approach to the drafting and interpretation of municipal government legislation. That led the Commission to conclude that:

[T]he purposeful language of the Municipal Government Act and the guidance of the courts require the Commission to narrowly interpret the authority assigned to it in Section 43 of the Municipal Government Act so as not to infringe upon the broad powers bestowed on municipalities to govern their affairs. ${ }^{93}$ $M G A$ which also brought significant re-ordering and re-numbering of the MGA.

K David Campbell Appeal on EPCOR Water Services Inc Water Rates for 2012-2017 (9 August 2013), 2013-295 at para 27, online: AUC < www.auc.ab.ca/regulatory documents/ProceedingDocuments/2013/ 2013-295.pdf> [AUC Decision 2013-295]. The implications of this phrase are discussed in more detail below.

$91 \quad$ MGA, supra note 2, s 43 [emphasis added]. There is a nearly identical provision in section 7(1) of the Distribution Tariff Regulation, supra note 84 creating an appeal right for a person who receives service from an REA. So far as we are aware, there are no decisions on this section of the regulation. There is also a very similar provision in section 30 of the GDA, supra note 10, although this section lacks the prohibition on challenging the rate structure itself. There are a number of Board or AUC decisions on this section of the GDA - see decisions referenced in supra note 10 . The section was carried in to the GDA from section 33 of the Rural Gas Act, SA 1994, c R-19.1. For a rather unique decision under the Rural Gas Act, see William and Darlene King, Edmund Kolesor and Warren Mueller Chinook Gas CoOp Ltd Complaints Alleging Discriminatory Charges (6 October 1997), U97119, online: EUB $<$ www.auc.ab.ca/regulatory_documents/ProceedingDocuments/1997/U97119.pdf>.

92 AUC Decision 22896-D01-2018, supra note 33. See also Town of Coaldale Appeal Pursuant to Section 43 of the Municipal Government Act (24 August 2018), 23159-D01-2018 at paras 45-52, online: AUC < www.auc.ab.ca/regulatory_documents/ProceedingDocuments/2018/23159-D01-2018.pdf $>$ [AUC Decision 23159-D01-2018].

93 AUC Decision 22896-D01-2018, ibid at para 30. 
The Commission concluded that it should not use general powers in its own legislation "so as to provide the Commission with authority not otherwise apparent on a plain reading of the limited jurisdiction" granted by section 43 of the $M G A .{ }^{94}$

\section{B. ELEMENTS OF THE COMMISSION'S JURISDICTION TO CONSIDER AN APPEAL}

In order for the Commission to establish jurisdiction to deal with an appeal under section 43 there must be: (1) a municipal utility service; (2) a person who uses, receives, or pays for that service; and (3) a service charge, rate, or toll in respect of that service.

\section{A Municipal Utility Service}

A party can only avail itself of the appeal mechanism of section 43 if the appeal is in relation to a municipal utility service. In a case involving rates charged for wastewater services by Leduc County, the County contested the jurisdiction of the AUC to hear the application in relation to some of the years covered by the application. ${ }^{95}$ The County took the position that during these particular years, the service was not provided by the County but by Northeast Pigeon Lake Regional Services Commission and that the County was merely a "billing intermediary for the Regional Services Commission." 96 The AUC rejected the contention, even while conceding that the County had no bylaw in place for these years. The AUC took the robust view that the service provided in the two years before the bylaw was adopted was essentially the same as that delivered under the bylaw. ${ }^{97}$ The service provided under the bylaw clearly fell within the definition of "public utility" within the meaning of the $M G A,{ }^{98}$ leading the AUC to conclude that "the wastewater fees charged in 2006 and 2007 are also fees for a municipal utility service." 99

The service must also be a utility service. While the definition of "utility" or "public utility" in the $M G A^{100}$ is now broad and includes both sewage and waste management (which are not included in the basic definition of public utility in the $P U A^{101}$ ), that has not always been the case. In a decision involving the Town of Calmar, the Board concluded that it could not consider a complaint relating to scavenging or garbage charges on the basis that this service was not included with the definition of a utility service at the time. ${ }^{102}$ The Board did, however, hope that the Town would consider the Board's ruling with respect to the

Ibid at para 31. This is also consistent with the guidance offered by the Supreme Court of Canada in the Stores Block decision (ATCO Gas and Pipelines Ltd v Alberta (Energy and Utilities Board), 2006 SCC 4).

Leduc County Appeal of Wastewater Disposal Rates (10 November 2010), 2010-526, online: AUC $<$ www.auc.ab.ca/regulatory documents/ProceedingDocuments/2010/2010-526.pdf $>$ [AUC Decision 2010-526].

Ruling on Motion of Leduc County to Limit the Scope of the Complaint and Hearing (13 August 2010), application No 1604906 at para 2, online: AUC <www2.auc.ab.ca/h005/Proceeding199/Proceeding Documents/AUC\%20Procee 0131.pdf>.

Ibid at para 10 .

Ibid at para 11.

Ibid at para 12. There is a form of "Catch 22" dilemma here. The Commission establishes jurisdiction even though there is no bylaw but then uses the absence of a valid bylaw to find for the applicant.

Supra note 2, s 1(1)(y).

See Macdonald Communities, supra note 2.

Mike F Hayduk and Town of Calmar (6 November 1987), E87114 at 19, PUB. 
appropriate basis for calculating water rates and "adopt a similar consistent practice with respect to scavenging." 103

In a more recent case, the Commission expressed concern that an appeal related to a "resident infrastructure fee" might be used for services that went beyond public utility services as defined in the MGA. ${ }^{104}$ The Commission eventually satisfied itself that the resident infrastructure fee was only applied by the municipality to water and sewer service, and thus concluded that it had jurisdiction to consider the appeal because the matter was in relation to a municipal utility service. ${ }^{105}$

\section{A “PERSON WHO USES, RECEIVES OR PAYS FOR A MUNICIPAL UTILITY SERVICE"}

An appeal may be launched by "[a] person who uses, receives or pays for a municipal utility service" (the current language of section 43 of the MGA). In the past, the orignal language of the provision in the MGA allowed for an appeal to be launched by "the user of a public utility." "106 Under the original language, the Board took the view that the term "user of a public utility ... refers to a customer to whom service charges, rates and tolls are made by the public utility for commodity consumed or service rendered to the premises." ${ }^{107}$ It follows from this that, where a municipality provides service to a multi-unit dwelling on a single meter and invoices the owner of the building, it is the owner of the building who is the user, and the occupants of the individual apartments would not be considered users. ${ }^{108}$ In a 1982 decision involving the County of Smoky Lake No. 13, the PUB ruled that the applicant was not a user of natural gas service since he had never signed a natural gas service contract as required under the County's rules. ${ }^{109}$ Therefore, he could not be liable for a monthly service charge. ${ }^{110}$

The current language in section 43 (that is, instead of "user" the reference is to "[a] person who uses, receives or pays for a municipal utility service") is broader and disjunctive. Thus, under the current scheme, a tenant in an apartment without an invoicing relationship with the utility might have standing to launch an appeal as a person who uses or receives municipal utility services. While such a tenant may have no incentive to do so if the landlord covers utility costs, the tenant may be so motivated if utility fees are flowed through to a tenant as a discrete and identifiable element of the rent.

Ibid.

Village of Alliance Appeal Pursuant to Section 43 of the Municipal Government Act (29 August 2018), 23398-D01-2018 at paras 50-55, online: AUC <www.auc.ab.ca/regulatory_documents/Proceeding Documents/2018/23398-D01-2018.pdf> [AUC Decision 23398-D01-2018].

Ibid.

The Municipal Government Act, SA 1968, c 68, s 280.

Re: Town of Bruderheim (28 March 1994), E94014 at 12, PUB.

Ibid for the majority (and at 24-25 for the dissent - but not on this point). See also to the same effect, Re: Town of Bassano (28 March 1994), E94013 at 16 (majority) and at 28 (dissenting but not on this point), PUB [PUB Decision E94013].

County of Smoky Lake No 13 / Horst Brenner (26 March 1982), E82108 at 13-15, PUB [PUB Decision E82108]. There is a possible inconsistency here in the Board's reasoning since, if Brenner (the applicant) was not a user, the Board might well have no jurisdiction to consider the matter - and it might therefore be an issue for the ordinary courts. The Board was perhaps sensitive to this issue insofar as the Decision expressly records that the County did not object to or question the Board's jurisdiction to process the complaint under section 291 of the MGA, supra note 2.

PUB Decision E82108, ibid at 16. 
In a decision dealing with the Town of Coaldale, the property in question was owned by one of the applicants (Eleanor Britz) but operated by all three applicants (Eleanor Britz, Nadine Britz, and Doug Shields) as a partnership. ${ }^{111}$ The Town addressed invoices for utility services to Eleanor Britz but the invoices were paid by Nadine Britz and Doug Shields. The Town took the position that none of the three applicants had standing to file an appeal since none of the three resided on the premises. The AUC rejected that argument. It concluded that in the circumstances all three were persons who use, receive, or pay for municipal utility services. $^{112}$

In order for a person to be included in an appeal, the municipality must have formal notice of that person's appeal. Thus, even if a person participates as a witness in a fellow complainant's application, that person will not be considered as a party to the appeal if they had not provided prior notice to the correct address. ${ }^{113}$ However, such a person might still be in a position to bring their complaint forward should the municipality not resolve any outstanding complaint. ${ }^{114}$

In a decision involving the City of Edmonton, the Commission expressly rejected the applicant's argument to the effect that any remedy should apply generally and not simply to himself as the applicant. ${ }^{115}$ The Commission reasoned that "the specific reference in Section 43 to the 'person's charge rate and toll' reflects the Alberta legislature's intention to grant the Commission only the limited authority to hear and decide appeals of a municipal utility's rates on an individual or complaint basis." 116 The Commission went on to say that section 43 "does not give the Commission the broad power to vary, adjust or disallow service charges, rates or tolls charged ... to other customers if they have not appealed their rates."117

\section{The TIMING OF AN APPLICATION}

In at least one case, the Commission has suggested that it may not even consider a case that is not brought in a timely manner. ${ }^{118}$ The Commission observed that relief under section 43 of the MGA is discretionary and then noted that it would be "in the public interest for it to limit its considerations of Section 43 appeals to those brought on a timely basis." 119 The Commission considered that such an approach would promote a number of principles. It would place "accountability on the person(s) appealing a utility service charge, rate or toll", it would provide "certainty and finality to municipalities and [their] customers in respect of their utility service charges, rates or tolls," and it would allow "municipalities to continue to

AUC Decision 23159-D01-2018, supra note 92. See also Coaldale (Town) v Britz, 2018 ABCA 392 [Coaldale], leave to appeal to the Alta CA refused. With respect to standing, the Court concluded that the issue raised a question of mixed fact and law and accordingly was not subject to appeal.

AUC Decision 23159-D01-2018, ibid at para 39. There is nothing in section 43(1) of the MGA that references residence.

See Town of Taber Conacher Water and Sewer Charges Complaint (25 September 2012), 2012-258 at para 54, online: AUC <www.auc.ab.ca/regulatory documents/ProceedingDocuments/2012/2012-258. pdf $>$ [AUC Decision 2012-258] and referring to Alberta Utilities Commission Act, SA 2007, c A-37.2, s $9(2)$.

AUC Decision 2012-258, ibid at para 55.

AUC Decision 2013-295, supra note 90 at paras 26-28.

Ibid at para 26 and referencing AUC Decision 2012-258, supra note 113 at para 88 under the heading "To whom do these findings apply."

AUC Decision 2013-295, supra note 90 at para 28.

AUC Decision 23159-D01-2018, supra note 92.

Ibid at para 53 [emphasis added]. 
operate public utilities on a cost effective basis." ${ }^{120}$ In applying this approach to the case at bar, the Commission observed that the applicants had raised questions about their utility bills many times over the years and could have brought a section 43 complaint as early as 2010 , but failed to do so until November 2017. In light of this, the Commission concluded as follows:

\begin{abstract}
In the Commission's view, the potential disallowance of approximately eight years of water, drainage, sewer and waste management service charge revenue for the property would not be fair to Coaldale in the circumstances, particularly given that services were provided to the property during this time and given that the complainants' fully controlled when the appeal was filed. Accordingly, the Commission finds that limiting its consideration of the appeal from November 12, 2015, which is two years prior to the date that the complainants filed the appeal, to present, is a reasonable balance of the Commission's authority to supervise municipalities under Section 43 of the Municipal Government Act, while recognizing the importance of the principles enunciated above, in the circumstances. ${ }^{121}$
\end{abstract}

In our view, this approach cannot be supported insofar as it suggests that the Commission should not even examine a complaint dating back more than two years. While the Commission ultimately has discretion as to whether or not to grant the relief sought, in whole or in part, this discretion is to be exercised once the Commission has examined the complaint. This is clear from the way in which section 43(2) is framed. The discretionary "may" is to be exercised once the Commission is satisfied that an applicant has established its case under one of the three headings. It is one thing for the Commission to conclude, having conducted an investigation, that it would be inappropriate to order relief; it is an entirely different matter to conclude that the lapse of time serves as a limitation or jurisdictional bar. ${ }^{122}$ The latter is incorrect.

\title{
4. An Appeal must Be in Respect of a Service Charge, RATE OR TOLL AND NOT IN RESPECT OF THE RATE STRUCTURE
}

Section 43 of the MGA allows a customer of a municipal utility to appeal a service charge, rate, or toll, but the appeal must not, in substance, be an appeal in respect of the rate structure. A decision from 2013 dealing with a complaint against EPCOR Water Services Inc. (EWSI) offers an extended discussion of the rate structure exclusion. ${ }^{123}$ In that case, the applicant took the view that EWSI rates were discriminatory insofar as some rates were calculated using inclining block rate structures whereas others involved declining block rate structures. ${ }^{124}$ Furthermore, the applicant took the view that uniform percentage increases for each rate class could not be justified absent a new cost of service study. From EWSI's

\footnotetext{
$120 \quad$ Ibid.

$121 \quad$ Ibid at para 55 .

It is also inconsistent with other board and commission decisions that have reached back much further than two years. See discussion below in Part III.D dealing with remedies.

123 AUC Decision 2013-295, supra note 90 at paras 29-35.

124 In an inclining block rate structure, the first $x$ cubic metres of supply are charged at one rate; incremental blocks $y$ and $\mathrm{z}$ are charged at successively higher rates. A declining block rate structure is the reverse.
} 
perspective, the applicant's complaints were effectively appeals with respect to the rate structure itself. The Commission offered the following general guidance:

\begin{abstract}
The Commission understands the phrase "rate structure" in Section 43 to generally mean the overall method or framework by which a municipal utility recovers its required revenues from customers. Elements of rate structure may include among other things the setting of customer classes, the use of rate blocks, the use of seasonal, and conservation or interruptible rates. In this case, elements of EWSI's rate structure are the setting of three separate customer classes and the employment of inclining and declining block rates for those customer classes.
\end{abstract}

In the Commission's view, the exclusion in Section 43 against challenging a municipal utility's rate structure prevents individual ratepayers from appealing their rates solely on the basis that they disagree with a municipality's overall approach for setting rates. For example, the exclusion prevents customers from appealing a municipality's decision to set two customer classes or to promote conservation by using an inclining rate block structure. This ensures that decisions about rate structure are made by a municipality and not by the AUC. However, the exclusion against challenging rate structure does not prevent a ratepayer from appealing charges, rates or tolls on the basis that they were improperly implemented or discriminatory. ${ }^{125}$

The Commission concluded that a complaint about the use of declining block rates for one class and inclining block rates for another was not a challenge to the rate structure itself, ${ }^{126}$ neither was a complaint about a utility applying a uniform percentage rate increase. Such a complaint was best interpreted as an argument that the rate was improperly imposed because it no longer reflected the cost causation principle. ${ }^{127}$ In the same decision, the Commission also noted that a complaint that challenges the manner in which a utility defines a rate class (for example, the cut-off for the number of units included in the class of multi-residential dwellings) "is very close to a challenge of rate structure." 128

It seems possible that characterizing an appeal as going to the rate structure may be closely related to the nature of the relief sought. If a successful claim can be remedied by rebating and reducing fees payable, such a claim is less likely to be characterized as an impermissible appeal about the rate structure. On the other hand, if a complaint can only be remedied by eliminating a rate class or creating a new rate class, then it is more likely to be classified as an appeal of the rate structure. A 2018 decision involving the City of Calgary illustrates this point. ${ }^{129}$ The Commission had summarily rejected an appeal on the basis that the applicant was attacking the City's established rate structure for wastewater charges. ${ }^{130}$ Essentially, the applicant took the position that the City needed to establish a class of

AUC Decision 2013-295, supra note 90 at paras 33-34.

Ibid at para 62.

Ibid at para 91 .

Ibid at para 49.

Letter from AUC to Ian Murdoch and Rob Speckman re: City of Calgary Appeal of Wastewater Rates Closure of Appeal (3 May 2018), online: AUC <www2.auc.ab.ca/Proceeding23579/Proceeding Documents/23579_X0003_2018-05-03AUCLetter-Closureofappeal_0003.pdf> [AUC Letter Closing Appeal]. The letter (from AUC Counsel) is available online in the file of the review and variance proceeding in this matter, AUC application No 23579; see Mr Ian Murdoch Review and Variance of a Commission decision dated May 3, 2018, dismissing an appeal pursuant to Section 43 of the Municipal Government Act (25 September 2018), 23579-D01-2018, online: AUC <www.auc.ab.ca/regulatory documents/ProceedingDocuments/2018/23579-D01-2018.pdf $>$ [AUC Decision 23579-D01-2018], for the outcome of the review and variance.

AUC Letter Closing Appeal, ibid at paras 7, 10. 
wastewater users for those customers who return less than 90 percent of their consumption to the wastewater system. ${ }^{131}$ The Commission considered that this "challenges the rate structure established by Calgary" "132 and that the Commission does not have the jurisdiction to entertain such an application or to order the creation of new rate classes. ${ }^{133}$ Accordingly, the Commission concluded that the appeal did not satisfy section 43 and closed the file. ${ }^{134}$ The Commission confirmed this understanding in a subsequent review and variance decision. $^{135}$

In an older decision involving an appeal of waste management charges imposed by the City of Edmonton, the EUB seems to have initially glossed over the requirement that the appeal must not be in respect of the rate structure itself. ${ }^{136}$ The City used different methods for billing multi-family residential buildings for different services. Thus, apartment suites were billed individually for electric power, but, in the case of water rates, apartment block owners received a single bill based on a single water meter for the entire building. In adopting fees for waste management services, the City followed the water model with the implication that an apartment owner received a bill for each suite multiplied by the number of suites in the apartment — regardless of whether the apartments were occupied or not and regardless of the amount of waste generated by each unit. By contrast, in the case of other types of multi-family residential units, the owner could opt for separate water meters and hence the occupants of those units would receive an individual garbage bill. Dominco, an owner of several apartment buildings that had experienced vacancies, argued that the resulting rates were discriminatory as against apartment building owners. The EUB agreed, noting that:

[T]he City's billing methodology contravenes two important rate design objectives; namely avoidance of undue discrimination and fairness of the rates in the apportionment of the total costs of service among the different consumers. In aligning the waste disposal account with the water account, the City is discriminating against the owners of high vacancy buildings, who are paying the same rates per unit as owners of low vacancy buildings, and yet are generating less waste and hence are reducing the cost the City experiences to serve the buildings. ${ }^{137}$

The EUB went on to require the City to file a set of rates that addressed the concerns identified by the Board. In its refiling, the City sought to comply by providing a rebate to owners of apartment buildings at year end based on vacancies, but the applicant took the view that the City had to bill on the electricity model. The City objected that this was going

The wastewater rate was based on metered water consumption; the higher the consumption, the higher the wastewater rate.

AUC Letter Closing Appeal, supra note 129 at para 7.

Ibid at para 10.

Ibid at para 17. However, the Commission also considered whether Murdoch's application established a case of discrimination. The Commission held at para 16 that it did not since the City had good reason to establish a single family residential rate class based upon the pattern of consumption of the class as a whole. This part of the decision was also affirmed in AUC Decision 23579-D01-2018, supra note 129 at paras $28-29$. online: EUB <www.auc.ab.ca/regulatory_documents/ProceedingDocuments/1997/U97089.pdf>. Ibid at 11 . 
"beyond the issue of discrimination and moving into areas related to rate structure." ${ }^{138}$ This time the EUB agreed with the City:

[T] o support such a determination [of undue discrimination] based upon cost causation, the difference in costs of providing service must be readily apparent and noncontentious. Otherwise, a meaningful examination of costs would require an extensive cost of service study and a full review of rate structure, which is beyond the Board's jurisdiction in this proceeding. ${ }^{139}$

Issues that go beyond public utility service charges, rates, and tolls are not within the limited authority of the AUC's jurisdiction under section 43 of the MGA. Thus, the Commission has concluded that it has no jurisdiction to deal with meter-related complaints. The "accuracy of measured amount, the type and functioning of the measurement equipment, the recording of measurement results, billing mechanics and the dispute procedures are all matters that fall within purview of the municipality," 140 rather than the Commission, and for which the municipality could best provide redress. ${ }^{141}$

Another example of a complaint that falls outside the rubric of "service charge, rate or toll" is a complaint in relation to the quality of service. Thus, in a decision involving Sturgeon County and complaints by the residents of the Namao Ridge Estates subdivision that the quality of water available to Namao residents was substantially lower than elsewhere in the County, the PUB considered that it did not have the jurisdiction to order improvements in water quality. ${ }^{142}$ However, it could determine "whether or not the charges imposed for water service are discriminatory on the basis of quality of service. If the charges do not reflect varying degrees of quality of service, such charges may well be discriminatory."143 The Board concluded that that was indeed the case and ruled that Namao customers should pay 50 percent of the charge payable by other customers. ${ }^{144}$

There may be some matters, however, that are ancillary to complaints with respect to a "service charge, rate or toll" that might be included within the Commission's jurisdiction. In a decision involving the Town of Coaldale, the Commission had to consider whether its jurisdiction with respect to public utility charges extended to a complaint that the Town had unlawfully added unpaid charges related to those services to a property tax invoice under the terms of section 553 of the MGA in order to facilitate recovery of those unpaid charges. ${ }^{145}$ The Commission reasoned that it had that jurisdiction. It observed that if it were to conclude that charges for a municipal utility service were improperly imposed for one of the reasons listed in section 43(2) and thus to be varied, adjusted, or disallowed, it would follow that

City of Edmonton Complaint from Dominco Plumbing \& Heating Limited (25 November 1998), U98178 at 3, online: EUB < www.auc.ab.ca/regulatory_documents/ProceedingDocuments/1998/U98178.pdf $>$. Ibid at 7 [emphasis added].

AUC Decision 22465-D01-2018, supra note 33 at para 39.

Ibid at para 40.

PUB Decision E79036, supra note 77.

Ibid at 17.

Ibid at 29-30 and also noting that the Board, while recognizing that it had no jurisdiction to order an improvement in water quality, would provide a copy of its decision to the Department of the Environment. 
those changes could not constitute unpaid charges within the meaning of section 553 that could be transferred to the tax roll. ${ }^{146}$ The Commission went on to state that:

\begin{abstract}
In the Commission's view, an interpretation that allows public utility service charges to be transferred to the tax roll under Section 553, but then insulates those same charges from appeal under Section 43, where such charges would have been varied, adjusted or disallowed by the Commission under Section 43(2) had they been appealed prior to being transferred to the tax roll, defeats the intention of the legislature in allowing a person to appeal the charge. ${ }^{147}$
\end{abstract}

The Court of Appeal declined to interfere with that interpretation. ${ }^{148}$

The next sections discuss each of the three grounds of appeal, namely that the person's service charge, rate, or toll: (1) does not conform to the public utility rate structure established by the municipality; (2) has been improperly imposed; or (3) is discriminatory.

\title{
C. Grounds OF APPEAL
}

\section{The Service Charge, Rate, or Toll Does not Conform to The Public Utility Rate Structure ESTABLISHED BY THE MUNICIPALITY}

This ground of appeal requires the Commission to assess the service charge, rate, or toll against the rate structure established by the municipality; that is, it is essentially an internal test of conformity - has the municipality followed its own rules? As noted above, the Commission considers that the term "rate structure," as used in this ground of appeal, means "the overall method or framework by which a municipal utility recovers its required revenues from customers."149

In order to assess whether or not a service charge, rate, or toll conforms to the rate structure established by the municipality, the Commission must necessarily interpret the bylaws that constitute the rate structure. ${ }^{150}$ The terms of the bylaw itself guide the Commission in deciding whether the rate structure was properly applied. ${ }^{151}$ The Commission

Ibid at para 50.

Ibid at para 51

Coaldale, supra note 111 per Strekaf JA observing that the Town's application was not sufficiently meritorious to grant permission to appeal whether the standard of review was reasonableness or correctness (at para 13). Under the Supreme Court of Canada's decision in Canada (Minister of Citizenship and Immigration) $v$ Vavilov, 2019 SCC 65, appellate review by the Court of Appeal of an AUC decision on a pure point of law will always be correctness.

AUC Decision 2013-295, supra note 90 at para 33. See also AUC Decision 23398-D01-2018, supra note 104 at para 27.

AUC Decision 2012-258, supra note 113 at paras 57-76. In this last case, the AUC concluded that during temporary discontinuance of service, the customer was not responsible for either fixed or variable charges. If the municipality wanted to continue to levy fixed charges during discontinuance, it needed to be specific. See also Re: Town of Bassano, (7 July 1993), C93025, PUB. This complaint was filed as a case of discrimination but the Board ruled that the town had levied a charge that did not comply with its bylaw.

AUC Decision 23398-D01-2018, supra note 104 at para 27; AUC Decision 23159-D01-2018, supra note 92 at para 57; AUC Decision 2012-258, supra note 113 at para 59; University of Alberta Appeal Respecting EPCOR Distribution Inc Transmission Charges (2 March 2004), 2004-021, online: EUB $<$ www.auc.ab.ca/ regulatory_documents/ProceedingDocuments/2004/2004-021.pdf $>$ [EUB Decision 2004-021]. 
will approach the interpretation of bylaws in much the same way as the interpretation of a statute. ${ }^{152}$ It will not interpret a bylaw based on a presumed understanding of utility ratemaking principles, but may take account of a municipality's actual practices. ${ }^{153}$

In an early PUB decision involving the Village of Onoway, each of the four applicants had a basement suite with a single tenant and yet were included in the multi-family residence rate class of the Village's water utility bylaw. ${ }^{154}$ The bylaw did not contain a definition of the word "family." 155 The Board found that the language of the bylaw was not sufficient to justify the Village charging a multi-family rate to the applicants, because the rented suites in the applicants' homes were occupied by only one person, rather than a family. ${ }^{156}$

In a decision involving the County of Smoky Lake, the Board had to consider the utility bylaw of the County as well as the County policy entitled "Standards, Regulations and Practices," which defined a "customer" of the County's gas utility as someone who had signed a contract for natural gas service. ${ }^{157}$ Since the complainant had never signed such a contract, the Board concluded that the charges were contrary to the County's rate structure and policy. ${ }^{158}$

In a more recent decision involving the Village of Alliance, the AUC had to determine whether the applicant was being charged in accordance with his rate class. ${ }^{159}$ That depended upon whether the applicant was properly classified as an "absentee resident" rather than as a "non-resident." The Commission observed that it was challenging to make this distinction given the absence of definitions in the bylaw, the inconsistent use of terms in the bylaw, and the Village's submission to the effect that terms in the bylaw had meanings that were at variance with their plain and ordinary meaning. ${ }^{160}$ One might have thought that would be enough for the Commission to find for the applicant, but in the end the Commission found that it was "plausible" to classify him as an "absentee resident." 161 The Commission did however offer the caution that in its view:

[A] bylaw should be clear and precise enough so that persons subject to the bylaw understand what they must do or not do in order to comply with the bylaw. While declaratory, the Commission expresses significant concern with the drafting quality of utility Bylaw 2015-01, and encourages the Village of Alliance to pursue opportunities to clarify its terms. ${ }^{162}$

AUC Decision 2012-258, ibid especially at para 63.

Ibid at paras $73-74$.

Harry Rothe and Melvin R Pedersen and The Village of Onoway (20 November 1969), 29620, PUB.

Ibid at 11 .

Ibid at 18 .

PUB Decision E82108, supra note 109.

Ibid at $14-15$.

AUC Decision 23398-D01-2018, supra note 104.

Ibid at para 75 .

Ibid at para 79 .

Ibid at para 81 . 


\section{The Service Charge, Rate, or Toll HAS BEEN IMPROPERLY IMPOSED}

Under this ground of appeal, the Commission must consider the powers and functions of a municipality and assess the legality of the utility service charge, rate, or toll. ${ }^{163}$ In effect, this is an external test of validity that assesses a municipality's bylaws against provincial statutes, in particular the MGA. For example, the Commission considers that a municipality may only make provision for public utility services by way of bylaw and may not proceed by way of resolution. ${ }^{164}$ Similarly, a municipality cannot backdate the effective date of a bylaw. A bylaw comes in to force when it is passed (that is, it receives third reading and is signed). ${ }^{165}$

A number of decisions falling within this ground of appeal deal with the requirement of section 42(2) of the MGA, which stipulates that where a municipality provides municipal utility service to an occupant of a parcel at the request of that person, then the resulting charge is an amount owing by the occupant and not the owner. While there may well be a factual issue to be resolved here (namely, was the service provided at the request of the occupant or the owner ${ }^{166}$ ), if the evidence demonstrates that the service was provided at the request of the occupant, the Commission and its predecessors have consistently disallowed any charges or associated penalties that the municipality seeks to recover from the owner based on this ground of appeal. ${ }^{167}$ This would be the case even if a municipal bylaw purported to authorize the recovery. ${ }^{168}$

In a decision involving the Sturgeon Council, the PUB interpreted "improperly imposed" to include the arbitrary application and forgiveness of certain water service charges. ${ }^{169}$ In that case, the County of Sturgeon had cancelled charges for some complaining customers, without the cancellations being first authorized by the Sturgeon Council. ${ }^{170}$ As well, the County had levied penalties against some customers improperly by applying a penalty charge to existing penalties, contrary to section $277(1)(\mathrm{b})$ of the 1970 MGA, which limited the penalty to 10 percent of the charges in arrears. ${ }^{171}$ The Board found that both the County's

Ibid at para 28 .

AUC Decision 2010-526, supra note 95 at paras 37-38. Amendments must also be made by bylaw (County of Thorhild Appeal of Water Rates at Long Lake (3 August 2016), 21497-D01-2016, online: AUC < www.auc.ab.ca/regulatory_documents/ProceedingDocuments/2016/21497-D01-2016.pdf > [AUC Decision 21497-D01-2016]).

New Vintage Homes and Town of Drumheller Bylaw 07.10 Appeal Pursuant to Section 43 of the Municipal Government Act (30 September 2010), 2010-462 at paras 60-68, online: AUC <www. auc.ab.ca/regulatory_documents/ProceedingDocuments/2010/2010-462.pdf $>$ [AUC Decision 2010-462] and referencing $M \overline{G A}$, supra note 2 , ss $1(1)(\mathrm{j}), 189,190(3)$.

See e.g. Mr and Mrs Lung Tak Lo Service Charges of Town of Claresholm (17 July 2002), 2002-062, online: EUB $<$ www.auc.ab.ca/regulatory documents/ProceedingDocuments/2002/2002-062.pdf $>$ [EUB Decision 2002-062]. The EUB resolved the factual dispute in favour of the applicant.

AUC Decision 23398-D01-2018, supra note 104 at paras 34-41 and referring to one decision of each of the Public Utilities Board (dealing with a previous version of the MGA) and of the Energy and Utilities Board: Roger Holton and Village of Legal (30 June 1987), E87049, PUB and EUB Decision 2002-062, ibid. Other decisions are perhaps more equivocal; see Board Member Report Respecting Mr Klaus Reichert Service Charges of City of Airdrie (2 September 2003), 2003-064 at 4-5, online: EUB $<$ www.auc.ab.ca/regulatory_documents/ProceedingDocuments/2003/2003-064.pdf > [EUB Decision 2003-064].

AUC Decision 23398-D01-2018, ibid at paras 42-46 and referencing MGA, supra note 2, s 13 which provides that a bylaw that is in conflict or inconsistent with the MGA is of no force or effect. PUB Decision E79036, supra note 77.

Ibid at 18 .

Ibid. 
arbitrary cancellation of charges and its practice of applying penalties to existing penalties constituted the improper imposition of charges for water service. The Board directed the County to discontinue these practices, not to recover the improperly cancelled charges, and to apply penalties consistently in the future. ${ }^{172}$

\section{The Service Charge, Rate, or Toll Is Discriminatory}

There are many decisions dealing with discrimination in the context of section 43 of the $M G A$ and its predecessor sections, as well as a broader body of jurisprudence that the EUB, PUB, and the Commission have occasionally brought to bear - especially in the early decisions of the PUB. ${ }^{173}$ Decisions with respect to discrimination are always fact specific, but it is possible to make some general observations.

First, while utility statutes generally proscribe unjust or undue discrimination, ${ }^{174}$ section 43 refers to discrimination simpliciter. Nevertheless, the PUB and the EUB have consistently taken the position that such a qualification was inherent in the concept of discrimination in this context ${ }^{175}$ and the AUC has continued that approach. ${ }^{176}$ Lines must inevitably be drawn between different rate classes based on the cost of providing service. The question is when does any resulting differentiation become unjust discrimination. ${ }^{177}$

Second, and related to the first point, it is not the fact of different treatment that is significant. The crucial question is whether there is a reasonable explanation for that different treatment. Different treatment will only constitute unjust or undue discrimination if it cannot be justified. The Commission put the point this way in a recent decision involving New Sarepta:

In assessing whether any service charge, rate or toll is sufficiently discriminatory so as to cause the Commission to act pursuant to Section 43 of the Municipal Government Act, the Commission must assess the presence or absence of any rationale or logic underlying the charges applied by a municipality to a customer, and finds it important to understand the whole context under which rates, tolls and charges are being imposed. ${ }^{178}$

For example, a municipality will need to justify a decision to grandparent existing customers or a class of customers from a change in policy. In a decision involving the Village of Delia, the Village had adopted a policy pursuant to which those who disconnected

\section{Ibid at 20}

See e.g. PUB Decision 29426, supra note 86 referencing Canada (AG) v The Corporation of Toronto (City of) (1893), 23 SCR 514; Hamilton (City of) $v$ The Hamilton Distillery Company (1907), 38 SCR 239; Halifax (City of) $v$ Read [1928] SCR 605.

See e.g. GUA, supra note 2, s 25; PUA, supra note 2, s 100; EUA, supra note 2, s 121(2)(b).

See e.g. PUB Decision E94013, supra note 108, the majority observing at 18 that: "It would not seem logical ... to conclude that legislators intended that the test applied to the rate structure of a municipallyowned utility would be more stringent than that imposed on utilities regulated by the Board pursuant to the PUB Act, which only prohibits 'unjustly discriminatory' rates." The dissent, at 27, was of the same view on this point

See among many decisions, EUB Decision 2004-021, supra note 151 at 8.

PUB Decision E94013, supra note 108 at 19.

New Sarepta Water and Sewer Complaint (24 February 2016), 20744-D01-2016 at para 32, online: AUC $<$ www.auc.ab.ca/regulatory_documents/ProceedingDocuments/2016/20744-D01-2016.pdf $>$ [AUC Decision 20744-D01-2016]. See also AUC Decision 24257-D01-2019, supra note 53 at paras 19-22. 
after the date of the bylaw would have to continue to pay utility charges. ${ }^{179}$ Those who were already disconnected would not be liable for utility charges, unless they reconnected and subsequently disconnected. The Commission concluded that the Village had been unable to justify grandparenting those who were already disconnected, even though the Village presented evidence that in adopting the new policy it had surveyed the practice of a number of other municipalities. Such a survey did not in and of itself "offer a reasonable rationale or fact-based justification for this differential approach."

Third, different treatment may take the form of differentiating between persons that are similarly situated, but it may also take the form of treating persons who are not similarly situated in the same manner. ${ }^{181}$ In the Village of Delia decision, the AUC stated:

In assessing an appeal under section 43(2)(c) of the Municipal Government Act, the Commission has held that discrimination can arise in two circumstances:

- First, when a utility fails to treat all its users equally where no reasonable distinction can be found between those favoured and those not favoured.

- Second, when a utility treats all its users equally where differences between users would justify different treatment. $^{182}$

Review based on the latter category poses a challenge for the AUC in the context of section 43 since, if an applicant establishes its case under this ground of appeal, the most effective, if not the only effective, remedy may be to require the municipality to create a new rate class; this runs the risk of falling afoul of the statutory language which precludes the Commission from considering challenges to the rate structure itself. ${ }^{183}$

Fourth, where the Commission identifies differential treatment, the municipal utility will bear the onus of justifying that differential treatment. The Commission has suggested that the bylaw itself should provide guidance on that justification. For example, in a recent decision concerning the Town of Devon, the Town had established a number of rate classes within the overall category of bulk water service rates but applied different rates to different users. ${ }^{184}$ Some users were charged a demand rate or basic monthly charge while others were not, and the different categories of rate class lacked clear definitions. ${ }^{185}$ This led the Commission to conclude that on a plain reading of the bylaw, even supported by evidence

Village of Delia Appeal of Utility Charges by Heide Peterson and Yvon Fournier (1 October 2019), 24678-D01-2019, online: AUC <www.auc.ab.ca/regulatory_documents/ProceedingDocuments/2019/ 24678-D01-2019.pdf $>$ [AUC Decision 24678-D01-2019].

Ibid at para 49. While there was evidence that some municipalities did charge fees to disconnected customers in order to cover fixed costs, Delia does not seem to have presented evidence of grandparenting as a common policy of other utilities.

For a recent example, see Town of Devon Appeal of Water Rates by Imperial Enterprises Inc (25 October 2019), 24435-D01-2019 at para 30, online: AUC <www.auc.ab.ca/regulatory_documents/ ProceedingDocuments/2019/24435-D01-2019.pdf> [AUC Decision 24435-D01-2019].

AUC Decision 24678-D01-2019, supra note 179 at para 42, citing AUC Decision 2012-363, supra note 10 at para 35.

See discussion above in Part III.B.4.

AUC Decision 24435-D01-2019, supra note 181.

Ibid at para 45 . 
adduced in the hearing, it could not identify a reasonable distinction between the applicant and other customers to justify the differential rates. ${ }^{186}$

An important decision involving the Town of Bashaw involved sewage charges levied against the owner of a mobile home park. ${ }^{187}$ The Town had established two rate classes: one large rate class for residential, commercial, and institutional users, and a second rate class exclusively for mobile home parks. The record suggests that there was only one mobile home park in the town. The PUB observed that the decision to create a rate class for the mobile home park "gives the appearance of discriminatory rates" even if that was not intended. ${ }^{188}$ It went on to conclude that the scheme was in fact discriminatory insofar as the charges imposed on the mobile home park owner did not reflect actual usage whereas the volumebased option available to all other customers did. ${ }^{189}$ In the end, the PUB ordered the Town to develop a rate for the mobile home park that was volume-based, even though that also required the town to install a flow measuring meter for the park. ${ }^{190}$

It is perhaps important to note that this decision, with its direction to create a new rate, was rendered before the MGA was amended in 1994. The amendments precluded a person from challenging the rate structure itself. Under the MGA as currently framed, it is not clear that the Commission would have been in a position to order this relief.

The Town sought leave to appeal. Justice Côté denied leave, reasoning that the PUB's direction to install a meter was "purely ancillary to following a rate structure which makes the charge dependent in part on the volumes." ${ }^{\text {"191 }}$ He also offered the following observation with respect to discrimination:

\footnotetext{
It was suggested in argument that if the practical workings and effect of different procedures for computing the charges to different people in fact produce the same charge, there is no discrimination. In my view that is not correct. In my view a municipality could not arbitrarily pick one consumer or class of consumers and for no rational reason establish a method of computation or no method of computation, but escape scrutiny by the Public Utilities Board simply on the grounds that as luck would have it the final number works out to be similar to that for consumers as a whole. ${ }^{192}$
}

The Commission and its predecessors have also declined to find discrimination in numerous cases. As might be anticipated, the Commission will be particularly reluctant to find discrimination if the municipality leads evidence, such as the results of a cost allocation study, to justify the distinctions that it has made. A case in point is a recent AUC decision involving the City of Calgary and Murdoch relating to wastewater charges. ${ }^{193}$ Murdoch argued that he was being overcharged for wastewater service on the basis that rates were calculated on a presumed return rate of metered water usage, while Murdoch claimed that

\footnotetext{
$186 \quad$ Ibid at para 51.

187 Re Russel Breseth Joan Braseth and Town of Bashaw (6 December 1989), E89112, PUB.

188 Ibid at 16.

189 Ibid at 19

190 This was required because the park provided its own source of water so there was no metering of water supply.

191 Bashaw (Town) v Alberta (Public Utilities Board), 1990 ABCA 187 at para 4.

$192 \quad$ Ibid at para 3

193 AUC Letter Closing Appeal, supra note 129.
} 
his return rate was much lower. It is worth quoting at some length from the Commission's decision:

The Commission accepts Calgary's evidence that it has separated its customers into six rate classes based on similar servicing and cost-causation demands, in accordance with industry practice.

The Commission accepts Calgary's position that the wastewater return factor represents the proportion of water used by a customer class that is contributed back to the wastewater collection system. This calculation approximates each customer class's demand on the wastewater system, as contributed wastewater is generally not measured. The return factors are not calculated at the individual customer level, but at the customer class level. These return factors are also used to determine the rates that will be applied to all customers within that customer class. As a result of the cost of service study, the wastewater return factor for the residential metered class was determined to be 90 per cent, which was approved in the wastewater bylaw.

The Commission is not satisfied that Mr. Murdoch's wastewater charges are discriminatory. Calgary has demonstrated both a rationale and logic for determining wastewater charges and for applying one wastewater return factor to the residential metered class. Calgary is treating all of the residential metered rate class equally, and given Calgary's current cost of service analysis, there appears to be no measurable difference between the various members of the residential metered class. ${ }^{194}$

In the New Sarepta case, the residents of the Hamlet of New Sarepta complained that they were charged different water sewer rates than other residents of Leduc County, despite being on similar lagoon systems. ${ }^{195}$ However, the Commission's examination revealed that there were good reasons for the differentiation. These reasons included the following: (1) the Hamlet was the sole user of a transmission line; (2) the Hamlet had an accumulated deficit before it amalgamated with the County; and (3) the Hamlet water system was distinct and separate from that of Leduc and had different operating and maintenance costs. ${ }^{196}$ In short, different costs justified different rates. ${ }^{197}$ Indeed, although the Commission does not say this, the imposition of identical rates would have resulted in discrimination against the other residents of the County and likely an unacceptable level of cross-subsidization by those other residents. 


\section{Remedies AVAilable TO THE \\ Alberta Utilities Commission When ONe or More Grounds For APPEAl ARE SATISFIED}

Section 43(2) of the MGA provides that if the AUC is satisfied that an applicant has established its case on one or more of the three listed grounds, the AUC "may order the charge, rate or toll to be wholly or partly varied, adjusted or disallowed." 198

Where the rates have been improperly imposed (for example, imposed by resolution rather than by bylaw, or imposed on the owner rather than the occupant), it would seem that the most appropriate remedy is disallowance of the rate, an order to refund any monies collected under the rate, and, if necessary, an order not to pursue recovery of charges under that rate. ${ }^{199}$

Where the rates have been found not to conform to the rate structure established by the municipality, it seems logical that the rate charged would be varied to a rate that is in conformity with the rate structure. That was the case for example in a decision involving the Town of Taber. ${ }^{200}$ The Commission held that a bylaw provision that suggested that a customer would not be responsible for "accruing rates" once a notice of discontinuance had been filed applied to both fixed and variable charges. Accordingly, the Commission directed a refund of amounts improperly collected. ${ }^{201}$

Where the rates are found to be discriminatory, it may be more appropriate to vary or adjust the rate rather than completely disallow it. For example, in the Town of Devon decision, the Commission, having concluded that the rate applied to the applicant was discriminatory, ordered that the applicant should have its commodity charge reduced to that payable by another bulk water consumer and a refund of any overage payable from the date that the applicable bylaw came in to force. ${ }^{202}$ Similarly, in the University of Alberta decision, the EUB concluded that the finding of discrimination meant that demand charges payable by the University should be based on its totalized peak demand as a customer (which would account for its self-generation) and not the individual peak demands at the individual feeders that provided it with service. ${ }^{203}$ This change would significantly reduce the demand charges payable by the University. ${ }^{204}$

There are other matters that the Commission may need to decide. First, given that section 43 uses the permissive "may," the Commission may have to decide whether or not there are circumstances that preclude relief, or circumstances that suggest that only part of the relief sought should be granted. Second, there might be questions as to how far back the Commission's decision should reach. Should it reach back to the time when the error was

MGA, supra note 2, $\mathrm{s} 43(2)$ [emphasis added] and see discussion below.

AUC Decision 2010-526, supra note 95 at para 65; AUC Decision 21497-D01-2016, supra note 164 at para 28; AUC Decision 23159-D01-2018, supra note 92 at paras 81-82; AUC Decision 23398-D012018, supra note 104 at para 89; EUB Decision 2002-062, supra note 166 at 6; EUB Decision 2003-064, supra note 167 at $8-9$.

AUC Decision 2012-258, supra note 113.

Ibid at paras 69-76.

AUC Decision 24435-D01-2019, supra note 181 at paras 53-55.

EUB Decision 2004-021, supra note 151.

Ibid. 
alleged to have been made? Or should it reach back only to the date of the complaint or some other date? Or should it be purely prospective?

As to the first, the Commission or Board has occasionally exercised its discretion to deny relief completely. For example, in a decision involving the Town of Drumheller, the Commission found that certain utility service charges, rates, or tolls had been improperly imposed for 17 days before the utility bylaw setting out the rates had come into effect. ${ }^{205}$ The Commission chose not to order any relief since any benefit which might have arisen from disallowance or variance of the charges improperly imposed for a short period of time would be offset by potentially creating increased administrative costs and confusion, to the detriment of all customers. ${ }^{206}$

As to the question of timing, the Commission has not been completely consistent. Although a remedy granted under section 43 of the MGA is not a remedial order under the terms of the Limitations Act, ${ }^{207}$ in one case involving the Town of Coaldale (discussed above $^{208}$ ), the Commission claimed to use its discretion to limit its consideration of section 43 appeals to those brought on a timely basis. ${ }^{209}$ It therefore declined to consider an appeal dealing with charges going back more than two years before the date of the application. The general trend, however, in cases involving nonconformity with rate structure or improper imposition of a charge is to reach back to the date identified by the applicant in its complaint as the date on which the issue arose. In some cases, the Board or Commission has reached back a long way, notwithstanding significant evidentiary difficulties. For example, in a case involving the Town of Claresholm commenced in 1999, the Board's decision rendered in 2002 dealt with alleged unpaid utility bills covering the period from November 1990 to January 1993. ${ }^{210}$ The case involved in part a factual dispute (resolved in favour of the applicant) as to whether the utility bills were the responsibility of the landowner or the tenant/occupant. ${ }^{211}$ The Board disallowed the charges over the entire period of the dispute.

The University of Alberta rate discrimination case triggered a discussion as to the effective date of the Board's order. ${ }^{212}$ The application, dated 26 November 2003 , asked the Board for relief effective 1 January 2002. The Board rejected arguments that the relief should only be prospective and in doing so seems to have been persuaded that given other Board decisions in the context of electricity deregulation, the utility should have anticipated that totalization or net metering would be required and that therefore it was reasonable to adopt the effective date proposed by the applicant. ${ }^{213}$

Sometimes applicants ask the Commission for remedies that go beyond those contemplated in section 43. Such was the case for example in the Conacher complaints

AUC Decision 2010-462, supra note 165 at para 68.

Ibid at para 69.

RSA 2000, c L-12. See EUB Decision 2003-064, supra note 167 at 4-5.

See discussion of AUC Decision 23159-D01-2018, supra note 92 in Part III.B.3 "The Timing of an Application."

Ibid at para 53

EUB Decision 2002-062, supra note 166.

Ibid.

EUB Decision 2004-021, supra note 151.

Ibid at 12-14. 
against the Town of Taber. ${ }^{214}$ In that case, the applicants asked the Commission to express disappointment as to the elected representatives of the Town, to admonish officers of the Town, levy fines under a town bylaw, and refer the complaint to the Municipal Government Board. The AUC found that these remedies were all beyond its jurisdiction under section 43 of the $M G A .{ }^{215}$ Similarly, the Commission has observed that it has no authority to make an order providing compensation for financial hardship or stress. ${ }^{216}$

In more recent decisions in which the AUC identifies an issue that goes beyond the three grounds of appeal listed in section 43, the Commission typically identifies the issue and then notes that there will be no further discussion of the point. For example, the Commission has observed that it has no authority to deal with: (1) allegations that the municipality is engaging in unfair competition with the applicant, ${ }^{217}$ or (2) a request that the applicant be grandparented (protected from the imposition of a new policy). ${ }^{218}$

The result of an appeal prima facie applies only with respect to the person or persons who launched or joined the appeal. ${ }^{219}$ This is consistent both with the idea that an appeal cannot challenge the "rate structure itself" but also with the language of section 43(2) which allows the Commission to vary, adjust, or disallow the relevant charge and so on, for that person. One implication of this is that the Commission has no jurisdiction to consider a complaint on the basis that other members of a rate class are discriminated against (rather than the rate class of which the applicant is a member). ${ }^{220}$

While the Commission has recognized the personal nature of the relief, it has also recognized that the result of a successful appeal may have implications for similarly situated individuals. This is illustrated in Commissioner Yahya's decision in an appeal involving the Town of Taber under the heading of "To whom do these findings apply":

The Commission, with respect to appeals of municipal utility charges, operates on a complaint basis. As such, these findings for the purpose of this decision are limited to the three complainants.... As such, the Commission will not order a general refund of these charges. The Commission, however, would encourage Taber to settle any other similar complaints based on similar circumstance that may arise from imposing these charges in order to avoid the burden of future hearings to deal with them. ${ }^{221}$

AUC Decision 2012-258, supra note 113.

Ibid at para 48 .

AUC Decision 23159-D01-2018, supra note 92 at para 43.

AUC Decision 24435-D01-2019, supra note 181 at para 29.

AUC Decision 24678-D01-2019, supra note 179 at para 19.

In some cases multiple parties may join an appeal. See e.g. AUC Decision 2010-526, supra note 95. The Nelsons initiated the appeal but 14 other parties joined the appeal.

AUC Decision 2013-295, supra note 90 at para 48. See also and to the same effect, AUC Decision 22465-D01-2018, supra note 33 and AUC Decision 22896-D01-2018, supra note 33 (issued on the same day).

AUC Decision 2012-258, supra note 113 at para 88 and also at para 54. See also Re The Summer Village of Alberta Beach (21 June 1994), E94039 at 22, PUB. 
The AUC emphasized the personal nature of the appeal jurisdiction in a later decision involving EWSI:

\begin{abstract}
Section 43 refers specifically to a "person's" service charge rate or toll and authorizes the Commission to vary, adjust or disallow that service charge rate or toll. This limited authority is in contrast to the broad authority conferred upon the Commission by Section 80 of the Public Utilities Act over public utilities and their owners. That section gives the Commission considerable authority to investigate whether the tolls charged by a public utility are just and reasonable and to vary or disallow the tolls and charges that, "...in its opinion, are excessive, unjust or unreasonable or unjustly discriminate between different persons or different municipalities.”
\end{abstract}

The Commission considers that the specific reference in Section 43 to the "person's charge rate and toll" reflects the Alberta legislature's intention to grant the Commission only the limited authority to hear and decide appeals of a municipal utility's rates on an individual or complaint basis. Had the Alberta legislature intended otherwise, it could have adopted the broader language found in Section 80 of the Public Utilities Act or it simply would not have empowered Alberta municipalities to regulate utilities of various kinds operating within municipal boundaries. ${ }^{222}$

In an early decision, the PUB took a more pragmatic view of this requirement in a case involving the Municipal District of Sturgeon No. 90, which dealt with complaints with respect to water quality and rates. ${ }^{223}$ The appeal was brought by a single individual but the evidence included a petition signed by 84 percent of the customers of a particular subdivision (the Namao subdivision). Notwithstanding that the applicant was not authorized to represent all Namao water customers in the matter, the Board concluded in light of the petition that the decision would apply to all Namao water customers since " $[\mathrm{t}] \mathrm{o}$ deal with the matter otherwise would in itself create discrimination within that group of Sturgeon water customers." 224

\title{
E. INTERVENTIONS
}

As noted in the last section, appeals under section 43 are individual in nature, but there is a sense in which an appeal may affect others who may be similarly situated, or customers within other rate classes who may end up having to pay a higher rate to cover amounts that have been collected, or would be collected in the future, under rates that have been held to violate one or more of the grounds listed in section 43(2). One might therefore anticipate that parties might seek to intervene to oppose or support an appeal. Interventions in these cases, however, appear to be rare, although not unknown. ${ }^{225}$ In a decision involving EPCOR Distribution Inc. (EDI) and the University of Alberta, interventions were filed by a consulting company representing West Edmonton Mall and by the Industrial Power

\footnotetext{
222 AUC Decision 2013-295, supra note 90 at paras 25-26 [footnotes omitted].

223 PUB Decision E79036, supra note 77.

$224 \quad$ Ibid at 17.

225 In AUC Decision 2013-295, supra note 90, in addition to EWSI and Campbell, the participants include
} the City of Edmonton and the Regional Water Customers Group. 
Consumers Association of Alberta (IPCAA). ${ }^{226}$ IPCAA was motivated to intervene because EDI had suggested that if the EUB granted the appeal, EDI would seek approval for a mechanism to recover from other rate payers the amounts it would have to refund. IPCAA was concerned that this might lead to retroactive ratemaking that would affect its members. In the end, EDI withdrew its request and accordingly the EUB did not comment further. ${ }^{227}$

\section{F. CONCLUSIONS}

The Commission and its predecessors have dealt with more than 35 appeals in the 50 years since the Board/Commission was first afforded supervisory jurisdiction over municipal utilities. The appeals have dealt with all three heads of appeal. The Commission routinely refers to its earlier section 43 decisions in dealing with appeals and has clearly sought to develop a consistent approach thereby providing guidance to municipalities. In doing so, the Commission is also cognizant of the limited nature of its jurisdiction and for the most part is careful to observe the deferential boundaries established by section 43 of the MGA.

We now turn to examine the Commission's somewhat broader jurisdiction under section 44 of the MGA.

\section{Disputes With ANOTher Municipality}

Section 44 of the MGA deals with the situation where one municipality provides another municipality with a utility service. Section 44 provides as follows:

(1) If

(a) a municipality is supplying a utility service to a person outside the municipality, and

(b) there is a dispute between the municipality supplying the utility service and any other municipality in connection with the rates, tolls or charges, the dispute may be submitted to the Alberta Utilities Commission.

(2) The Commission may make an order on any terms and conditions that it considers proper.

(3) This section applies whether or not a public utility is subject to the control and orders of the Alberta Utilities Commission pursuant to section 111 of the Public Utilities Act or section 4 of the Gas Utilities Act. $^{228}$

Section 44 must be read in the context of section 45 , which suggests that there will frequently (if not invariably) be a franchise agreement ${ }^{229}$ in place where some other person

226 EUB Decision 2004-021, supra note 151 at 2.

227 Ibid.

$228 \quad$ MGA, supra note 2 , s 44.

See discussion of franchise agreements above in Part II.C. It may be a matter for debate as to whether utility services can only be provided by another person under the terms of a franchise agreement. While section 45 of the MGA, supra note 2 and section 139 of the EUA, supra note 2 (in the case of an electric distribution utility) - and there are similar provisions in the GUA, supra note 2 and the PUA, supra note 2 - deal with the granting of rights (and thus suggest the need for a franchise agreement and AUC approval) sections 33 and 46 of the MGA seem to contemplate that it will be up to a municipality to pass a bylaw that prohibits persons from providing utility service. In other words the prohibition would have to come from a bylaw, not the $M G A$ itself. 
(which includes another municipality) (230 $^{2}$ supplies a utility service within the boundaries of a municipality. Hence, disputes arising between the two municipalities may well involve the interpretation of such agreements.

In order for the Commission to have jurisdiction under section 44, there must be a dispute "in connection with the rates, tolls or charges." Either municipality may submit the dispute to the Commission. ${ }^{231}$ In its consideration of the dispute, "[ $\left.\mathrm{t}\right]$ he Commission may make an order on any terms and conditions that it considers proper." It is hard to imagine a broader conferral of authority and discretion once the Commission is satisfied that it can assume jurisdiction.

There have been only five decisions rendered by the Commission and its predecessors under section 44 and the earlier comparable provisions, section 276 of the pre-1980 version of the MGA and section 286 between 1980 and 1994. Four of those decisions involved water rates and one involved natural gas rates. Of the four water rates cases, three have engaged the terms under which the City of Edmonton supplies water to a number of adjacent municipalities and regional service commissions collectively known as the Edmonton Regional Water Customers Group (ERWCG) (referred to here as the Edmonton Water Rates Cases). ${ }^{232}$

We will examine the three Edmonton water rates cases first and then turn to the other two decisions before summarizing the key findings with respect to the AUC's section 44 jurisdiction.

\section{A. Edmonton Water Rates Case No. 1}

In the first of these three decisions, the PUB, as it then was, took the view that the authority to establish such terms and conditions as to the Board seemed proper under what was then section 276(4) of the MGA, "clearly confers jurisdiction on the Board to determine

Sturgeon County and the Town of Legal Water Rates for the Morinville Regional Waterline (26 April 2011), 2011-147 at paras 45-47, online: AUC <www.auc.ab.ca/regulatory documents/Proceeding Documents/2011/2011-147.pdf> [AUC Decision 2011-147]; AUC Decision 2010-222, supra note 5 at para 54 .

231 The section does not explicitly provide for this but the cases considered here have all been brought on by one party and the section could not serve its protective function if both municipalities had to agree to refer a dispute to the Commission. Furthermore, it seems clear that only a municipality may commence the application; an individual rate payer has no standing under this section of the MGA to bring a dispute before the AUC.

232 County of Strathcona No 20, County of Parkland No 31, City of St Albert, Towns of Stony Plain and Spruce Grove Water Rates (30 January 1979), E79015, PUB [Edmonton Water Rates Case No. 1]; Re: City of Edmonton (15 June 1995), E95070, EUB [Edmonton Water Rates Case No. 2]; Regional Water Customers Group Rates for Water Supplied by EPCOR Water Services Inc to RWCG for 2004, 2005, 2006 and 2007 (28 June 2011), 2011-281, online: AUC <www.auc.ab.ca/regulatory documents/ ProceedingDocuments/2011/2011-281.pdf $>$ [Edmonton Water Rates Case No. 3]. There were also two compliance filings in this matter: see EPCOR Water Services Inc Regional Water Customers Group Rates for Water Supplied by EPCOR Water Services Inc to RWCG for 2004, 2005, 2006 and 2007 (12 April 2012), 2012-102, online: AUC < www.auc.ab.ca/regulatory documents/ProceedingDocuments/ 2012/2012-102.pdf> [AUC Decision 2012-102] and EPCOR Water Services Inc Regional Water Customers Group Rates for 2004, 2005, 2006 and 2007 Second Refiling (3 August 2012), 2012-208, online: AUC < www.auc.ab.ca/regulatory_documents/ProceedingDocuments/2012/2012-208.pdf $>$. One other matter seems to have been settled: see AUC Application No. 1333552, Water Rate Dispute between the Town of Three Hills and the County of Kneehill (2004). Water Rate Dispute between the Town of Three Hills and the County of Kneehill (2004), online: AUB <www.auc.ab.ca/regulatory documents/ProceedingDocuments/2004/1333552_Application.pdf\#search=1333552>. 
just and reasonable rates to be charged for a utility service rendered by one municipality to another, when those rates are in dispute." ${ }^{.233}$ Later in the same decision, the PUB observed that while the rate setting provisions of the PUA were inapplicable (since the Act then, as now, expressly stipulated that these provisions did not apply to a municipally owned utility unless it had expressly brought itself under the $A c t^{234}$ ), the Board could use those provisions as a guide, especially since section 276(4) "provides no direction."235

In the first decision, the applicant municipalities contested the manner by which the City allocated costs to the municipalities for the delivery of water-using facilities that provided a service for both the City and the municipalities. In its decision, the Board carefully examined the cost allocation study that had been prepared for the City. ${ }^{236}$ The Board evidently agreed with some of those elements but disagreed with others and adjusted the cost allocation accordingly. For example, the Board noted that the municipalities themselves provided the incremental capacity required for fire protection flows through pumps and reservoirs, and that therefore there should be no allowance for fire flow requirements in the costs allocated to the municipalities. ${ }^{237}$ Similarly, the Board concluded that the rate classes developed by the City were based on location within corporate boundaries rather than distance, which would be more reflective of the cost of service. The Board ruled that cost allocation based on corporate boundaries constituted unjust discrimination. ${ }^{238}$

The decision also contains an interesting discussion of how the PUB should approach the cost of capital in the context of a municipal water utility. The Board generally seems to have been of the view that the City's risk was lower than that faced by an investor-owned energy or communications utility. The Board observed that water has no substitute and is virtually price inelastic. Furthermore, as a municipal utility, the City would be in a position to respond to changes and make adjustments without needing to go through a time-consuming Board prior approval process for any changes in rates. ${ }^{239}$ The Board also rejected the City's argument that a different rate of return should apply to the share of the rate base attributable to the applicant municipalities insofar as that was allegedly subject to greater risk. In the Board's view, the risk was the same and it was low. ${ }^{240}$

The main conclusion to be drawn from this review is that the Board's jurisdiction under section 276 (now section 44) is far wider than its jurisdiction under what was then sections 290 or 291 (now section 43). Indeed, in this first decision, the Board engaged in the same sort of approach and analysis as it would in a general rate application to establish just and reasonable rates - but only with respect to rates payable by the applicant municipalities not with respect to that part of the system that is providing services within the City's boundaries. The Board is perhaps somewhat hampered in its assessment by the fact that applicant municipalities must take the lead (rather than the utility itself as would be the case

Edmonton Water Rates Case No. 1, ibid at 8.

Ibid at 6-6 and see discussion of the current PUA legislation in Part II.E. Ibid at 70 .

In fact, the Board required ERWCG to lead (since they were the applicants) whereas in a normal rate case, it would be the utility that would lead with the presentation of its case (ibid at 11). This meant that in large part the applicants presented a critique of the City's cost allocation study. Ibid at $42-44$.

Ibid at $47-48$.

Ibid at 59-60.

Ibid at 62 . 
if it were making an application for approval of just and reasonable rates) and therefore the information asymmetry that is always present as between the utility, its customers, and the regulator may be exacerbated.

\section{B. Edmonton Water Rates CaSe No. 2}

The EUB began its second decision by observing that since the first decision rendered in 1979, the parties had been able to successfully negotiate arrangements, but were not successful in doing so for 1993, thereby necessitating the current application. ${ }^{241}$ The EUB did not make a specific issue in this decision as to who should take the lead in presenting the case, but the layout of the decision is such that each part of the decision begins with a statement of the City's proposal, followed by a statement of the ERWCG's position and argument, and then that of the City.

This decision, perhaps even more so than the first, reads like a typical utility rates decision with sections of the decision dealing with rate base, capital structure, contributions in aid of construction, and return on common equity. The most significant issues again were cost allocation issues and the concern to ensure that the applicants did not bear an inappropriate share of facilities constructed principally or even exclusively for the benefit of Edmonton customers. ${ }^{242}$ It is useful to observe that the EUB had no hesitation in expressing prescriptive views as to the structure of rate classes. Thus, based on the relative homogeneity of the applicants and conditions of service under which they operated, the Board concluded that the applicants should be treated as one customer class and found "no merit in the position of Edmonton Water that each Regional Customer is a distinct rate class."243 This also had implications for the calculation of demand charge since the Board was of the view that this should be based on coincidental flows of the class as a whole at the time of coincident system peak. $^{244}$

Costs became an issue for the first time in this decision. In the first decision, neither party applied for costs and none were assessed. ${ }^{245}$ In this case, ERWCG argued that Edmonton Water should be responsible for its costs. The Board rejected that on the basis that most of ERWCG's arguments were centred on self-interest (cost allocation issues) rather than system wide interests. However, the same was also true of Edmonton Water's positions. Accordingly, the Board directed that Edmonton Water should "absorb its own external costs and that these costs not be charged to Regional Customers' revenue requirement in any form." 246

$241 \quad$ Edmonton Water Rates Case No. 2, supra note 232 at 9.

${ }_{242}$ See in particular, the allocation of responsibility for the costs of abandoned projects, ibid at 50-55.

243 Ibid at 60.

$244 \quad$ Ibid at 63.

245 Ibid at 102.

246 Ibid at 103. The Board issued two orders clarifying the intent of the main decision: Re: The City of Edmonton (22 June 1995), Order E95072 PUB and Re: The City of Edmonton (14 March 1986), Order U96026, online: PUB <www.auc.ab.ca/regulatory_documents/ProceedingDocuments/1996/U96026. pdf $>$. 


\section{Edmonton Water Rates Case No. 3}

In this case, the applicants, now known as the Regional Water Customers Group (RWCG), applied to have the AUC determine the rates for water supplied and delivered by Edmonton Water, now known as EWSI, for the years 2004 to 2007. ${ }^{247}$ The AUC acknowledged that it could assume jurisdiction over the matter under both section 44 of the MGA and under what was then section 47.1. This latter section, now repealed, ${ }^{248}$ specifically provided that sections 43 to 47 of the MGA applied in respect of a utility service provided by EWSI, and that in the case of any dispute between a regional services commission and EWSI with respect to rates, tolls, or charges for a service that is a public utility "any party involved in the dispute" may submit it to the AUC and the AUC "may issue an order on any terms and conditions that ... [it] considers appropriate." $" 249$

While section 44 uses "proper" as the measure for the AUC's intervention, section 47.1 adopted "appropriate." To the Commission, however, there was no difference. It observed that it would "proceed to address and resolve the disputed rates, tolls, and charges for this water service on such terms and conditions as the Commission considers both proper and appropriate. The Commission considers that for this purpose there is no distinction in intended meaning between what is proper and what is appropriate." 250

The AUC took the view that although the application was not filed until 2006, it could be applicable to all the years that were the subject of the application on the basis that all of the issues between the parties related to the clarification of existing rates as well as the balancing fund. The balancing fund was effectively a deferral account, and rates subject to a deferral account are not final rates. Consequently, rulings as to the ultimate disposition of a deferral account constitute a recognized exception to the prohibition against retroactive or retrospective rate-making. ${ }^{251}$

Once again, most of the attention focused on the appropriateness of the cost allocations implemented or proposed by EWSI. For example, EWSI had begun allocating costs as between transmission and distribution functions on the basis of a 30:70 ratio. Yet the evidence showed that the distribution system was growing faster than the transmission system. This was of concern to the RWCG, since transmission costs were shared while

247 Edmonton Water Rates Case No. 3, supra note 232.

248 See Modernized Municipal Government Act, SA 2016, c 24, s 8

249 MGA, supra note 2, s 47.1 as it appeared on 6 December 2007. It is perhaps notable that this provision clarified that the application could be made by either party.

250 Edmonton Water Rates Case No. 3, supra note 232 at para 22. There was also some discussion as whether or not Part 2 of the PUA was relevant. In the end however, the Commission ruled that (ibid) “ reference was not considered necessary nor made to Part 2 of the Public Utilities Act and no reliance was placed on its provisions."

251 Edmonton Water Rates Case No. 3, ibid at para 23. The Commission refers here to Calgary (City) $v$ Alberta (Energy and Utilities Board), 2010 ABCA 132. See also Bell Canada v Bell Aliant Regional Communications, 2009 SCC 40 as well as the Commission's own jurisprudence in the line loss saga: Milner Power Inc Complaints regarding the ISO Transmission Loss Factor Rule and Loss Factor Methodology ATCO Power Ltd Complaint regarding the ISO Transmission Loss Factor Rule and Loss Factor Methodology Phase 2 Module A (20 January 2015), 790-D02-2015, online: AUC <www.auc.ab. ca/regulatory_documents/ProceedingDocuments/2015/790-D02-2015.pdf $>$. 
EWSI's customers were solely responsible for distribution costs. The Commission recognized this concern:

The transmission and distribution portions of the water system do not grow in parallel. As such, a fixed percentage allocation to transmission and distribution does not reflect the dynamic nature of the system. An acceptable methodology used to allocate transmission and distribution mains should reflect the dynamic growth of the system. Therefore, the Commission considers that a fixed percentage fails to reflect how the system has changed and continues to change. ${ }^{252}$

The Commission therefore directed EWSI to return to a previous allocation formula that both parties had accepted. ${ }^{253}$ Another allocation issue involved the responsibility for water losses. In this case however, the AUC, citing the lack of necessary information, directed the parties to continue using an existing allocation formula while also requiring EWSI to undertake a cost allocation study with future "[w]ater loss adjustments ... to be set in accordance with the conclusions of this study." 254

The AUC also made some more general rulings. For example, noting that increases in EWSI's corporate service costs were substantially above inflation costs, the AUC ordered EWSI to limit the level of those increases. ${ }^{255}$ The AUC also reviewed and reaffirmed EWSI's approach with respect to traditional utility matters such as capital structure and cost of capital (both debt and equity), ${ }^{256}$ and corrected EWSI's approach to the treatment of an allowance for funds used during construction. ${ }^{257}$

Costs also became an issue in this case, especially in relation to the protracted compliance proceedings. The Commission affirmed the general rule that in rate applications, parties with adequate means, including municipalities, should bear their own costs. The Commission observed that the rationale and policy for that rule was equally applicable to section 44 complaint proceedings. However, since the RWCG had been largely successful in its complaint, EWSI's costs should not be included in any charges to RWCG. The AUC took a different position in the case of the compliance proceedings. The Commission characterized EWSI's behaviour as a "delinquency [that] needlessly protracted" the proceedings and ordered an award of costs against EWSI with respect to the compliance proceedings. ${ }^{258}$

\section{The Morinville Regional WATER Line Decision}

This inter-municipal dispute also engaged water rates payable on a regional water transmission line. ${ }^{259}$ The line in question, the Morinville Regional Waterline, was built in the

Edmonton Water Rates Case No. 3 supra note 232 at para 33.

Ibid at para 35 .

Ibid at para 61 .

Ibid at paras $110-11$.

Ibid at paras $125-59$.

Ibid at paras $170-76$.

AUC Decision 2012-102, supra note 232 at para 64.

The application first came before the AUC as Sturgeon County and the Town of Legal Proposed Revised Water Supply Agreement with the Town of Morinville (16 October 2008), 2008-099, online: AUC $<$ www.auc.ab.ca/regulatory_documents/ProceedingDocuments/2008/2008-099.pdf $>$. The application was resubmitted and eventually decided as AUC Decision 2011-147, supra note 230. 
1980s to take water from the City of Edmonton ringline north to the Town of Morinville. It was oversized when built to provide capacity to deliver water in the future to the Town of Legal and Sturgeon County. The line was financed through a cost sharing arrangement between Morinville and the province. As part of that arrangement, the province paid the costs associated with the additional capacity with a view to assigning those capacity rights in the future to Legal and the County. Ultimately, that was what transpired and both Legal and the County entered into Water Supply Agreements (WSAs) with Morinville in 1989 and 1992 respectively. After some adjustments, capacity was ultimately allocated 23.3 percent to the County, 12 percent to Legal, and 64.7 percent to Morinville. ${ }^{260}$

With the expiry of the County agreement, Morinville sought to change the terms of the WSA. That led to disagreements between the parties and ultimately to the first of two applications before the AUC brought by Legal and the County. The first application was firmly based on section 44 of the MGA, but at that time the panel of the AUC hearing the matter expressed some doubts as to whether section 44 provided a sufficient jurisdictional basis to consider the matter. The panel did not make a final ruling on the scope of section 44 but did suggest that the AUC would clearly have authority to consider the dispute under the terms of section 112 of the PUA. It therefore gave leave to the applicants to re-file under section 112, while ordering Morinville, in the interim, to continue to supply and deliver water under the terms of the original WSAs.

Section 112 of the PUA contains a specific authority that allows a municipality to apply to the AUC to order a "proprietor municipality" "to deliver, supply and furnish water at a place to be designated by the Commission and to do so on the terms and conditions the Commission considers proper." 261 A "proprietor municipality" is "a municipality that owns, operates, manages or controls a public utility." 262 Section 112(4) states:

Part 2 [of the PUA] applies, with all necessary modifications, to a public utility within any area to which this section applies and in respect of any public utility of a proprietor municipality as though a bylaw had been passed and approved by the Lieutenant Governor in Council under section 111 bringing its public utility under this Act. ${ }^{263}$

Part 2 of the PUA contains all of the substantive provisions conferring on the AUC the authority to establish just and reasonable rates for a utility. The County and Legal followed the Panel's advice and the matter came back before the AUC.

In this second proceeding however, the new panel of the AUC, while reaffirming that it had jurisdiction under section 112 of the PUA, clearly believed it was important to fully explore a possible complementary jurisdiction under the $M G A$, principally perhaps because of section 47, the continuity provision (as we will refer to it) in the $M G A .{ }^{264}$ This is the provision that stipulates that a franchise agreement (approved under section 45) that reaches the end of its term without an agreed renewal, continues in effect until either party terminates

\footnotetext{
260 AUC Decision 2011-147, ibid at paras 11-19.

261 PUA, supra note 2 , s $112(3)(\mathrm{a})$.

$262 \quad$ Ibid, s $112(2)(\mathrm{b})$.

263 Ibid, s $112(4)$.

264 AUC Decision 2011-147, supra note 230 at paras 43-46.
} 
it on six months' notice, but only with the approval of the AUC. ${ }^{265}$ This required the Commission to assess whether the WSAs qualified as franchise agreements under sections 45 and 47. The Commission so held, concluding that a municipality was a person for the purposes of section 45(1) and Legal's WSA had been approved by the PUB under the predecessor provision to section 45 of the MGA. ${ }^{266}$ While the County's WSA had not been approved by the PUB, the Commission nevertheless concluded that:

[T] he Sturgeon WSA is the type of agreement described in Section 45 of the Municipal Government Act. Moreover, the Commission notes that the applicants and Morinville have treated and applied the Sturgeon and Legal WSAs in the same way. Specifically the WSAs are nearly identical, with very similar terms for service and Morinville has continued to provide water service despite the expiry of the term specified in the WSAs. $^{267}$

The Commission determined that it had jurisdiction under section 44 of the MGA as well as under section 112 of the $P U A .{ }^{268}$ Both sections afford the Commission a broad jurisdiction and discretion to establish terms and conditions for service that the Commission "considers proper," although section 112 of the PUA, as noted above, expressly incorporates Part 2 of the PUA which would offer a more structured approach to rate setting. ${ }^{269}$

The Commission then turned to consider how rates should be established on a go forward basis. Morinville argued that rates should be established on a traditional rate-base, rate of return methodology. The Commission, however, concluded that this would be an inappropriate methodology, principally because the funding model adopted by the province to support the financing of the pipeline effectively resulted in a coventure or co-ownership model, at least with respect to capacity. The relationship between the parties was not that of utility owner/customer, ${ }^{270}$ and there was no conventional rate base. The Commission recognized that the relationship was sui generis and thus did not award Morinville a return on invested capital. Each party was effectively responsible for its own cost of capital associated with its capacity entitlement. ${ }^{271}$ The AUC did however award Morinville a fee "for its stewardship or management of the system for the benefit of all three parties and their residents." 272

The Commission made some other more conventional rulings as well. For example, it ordered that operating and maintenance expenses be allocated on the basis of the allocation of capacity rather than on the basis of delivered volumes of water on the understanding that this was the most fair and reasonable way of allocating largely fixed costs. ${ }^{273}$

This decision serves to emphasize that the Commission has significant discretion under section 44 of the MGA and that it will exercise that discretion in a manner that is appropriate

See previous discussion in Part II.C, "Franchise Agreements." AUC Decision 2011-147, supra note 230 at paras 45-48.

Ibid at para 48 .

Ibid at para 47.

For example, if Part 2 of the PUA, supra note 2 applied, arguably the AUC would have to establish a rate base following the methodology of section 90 of the PUA.

AUC Decision 2011-147, supra note 230, at paras 52-77.

See ibid at paras 107-109.

Ibid at para 85 .

Ibid at para 98 . 
to the particular context. Some cases may require the application of traditional cost of service methodology but in other cases, as here, a more flexible and indeed sui generis approach may be appropriate. ${ }^{274}$

\section{E. Natural Gas Dispute Between the Town of RedClifF AND THE CiTY OF MEDICINE HAT}

In 1986, the Town of Redcliff entered into a gas supply agreement (GSA) with the City of Medicine Hat. ${ }^{275}$ The GSA gave the City the right to supply and distribute natural gas within the Town. At the same time, the Town sold its natural gas utility and production assets to the City. Under the price provisions of the GSA, the commodity price of gas after a transitional period was to be the same as that established by the City for its customers within its boundaries. The GSA expired in 1986. It was never approved by the PUB as a franchise agreement but, according to the AUC, "the parties have considered the Agreement as a franchise agreement and have acted accordingly." 276 An important implication of this conclusion is that, as in the Morinville case, the GSA continued automatically under the terms of section 47 of the MGA pending the approval of the AUC to terminate. On the basis of these continuation rules, the Town's customers were paying three types of rates or charges: a rate to cover distribution expenses, a rate representing the gas commodity price, and an energy conservation charge. The Town's customers paid at the same rate for all three charges as City customers. The current dispute covered the years of 2006, 2007, and 2008. The Town took the position that the first two rates or charges were not established in accordance with Alberta regulatory principles and did not result in just and reasonable rates, while the third rate was an illegal tax.

The AUC's examination of the matter revealed that for much, if not all, of the period of the GSA, the City had effectively subsidized the commodity price of natural gas to the benefit of both its residents and those of the Town. However, following studies in 2003 and 2004, the City resolved to move to market prices, which it did over the years at issue in the dispute (2006 to 2008). ${ }^{277}$ At around the same time (beginning in 2003), amendments to the GUA allowed all consumers to contract with a competitive retailer. Several greenhouse operators, for example, took advantage of this and as a result, they would have paid the City's gas distribution rates and the gas commodity price charged by their supplier or retailer. ${ }^{278}$

The AUC confirmed that it could assume jurisdiction over the dispute under section 44 of the $M G A,{ }^{279}$ but also suggested that it could take jurisdiction under both section 17 of the GUA and section 81 of the PUA. These are parallel provisions in the two utility statutes which provide that where there is a contract for the supply of a commodity or service

For the AUC decision on the compliance filing see Town of Morinville - Morinville Regional Waterline Compliance Filing Pursuant to Decision 2011-147 (17 January 2012), 2012-020, online: AUC <www. auc.ab.ca/regulatory_documents/ProceedingDocuments/2012/2012-020.pdf $>$; and for the decision on costs see Sturgeon County and the Town of Legal Cost Decision (7 October 2011), 2011-402, online: AUC < www.auc.ab.ca/regulatory_documents/ProceedingDocuments/2011/2011-402.pdf $>$.

AUC Decision 2010-222, supra note 5.

276 Ibid at para 13. The Commission found the Agreement functioned as a franchise agreement (para 68).

277 Ibid at paras $18-24$.

$278 \quad$ Ibid at paras $28-29$

$279 \quad$ Ibid at para 59. 
between a public utility and a municipality or person, then any party to that contract may apply to have the Commission, "notwithstanding anything in this Act," review the terms of the arrangement and establish the tolls, charges, or rates that "it considers fair and reasonable." ${ }^{280}$ While the Commission referenced these sections, it seems to have relied principally, if not exclusively, on section 44 of the $M G A .{ }^{281}$ In describing its jurisdiction under section 44 of the MGA in the context of this application, the AUC emphasized that it was not dealing with an application to set rates but rather with a dispute over rates previously charged - but it went on to observe that "if it were to find that the circumstances warrant a full review of the rates charged by the City to customers in Redcliff, it could make such an order." 282

In the end, the AUC concluded that it would be inappropriate to grant the Town the relief it requested for three main reasons. First, it observed that under the terms of the GSA, the Town had effectively accepted the extra-municipal application of the City's rate setting bylaw and thus had accepted a less formal and more political process than that which would be administered by the Commission. ${ }^{283}$ But that also meant that the Town would be excluded from the City's political process. That led the Commission to observe that it would expect to see the City adopt some process providing the Town with notice and a reasonable opportunity to participate when it was contemplating changes. ${ }^{284}$ In this case however, the Commission concluded that this requirement had been met. ${ }^{285}$

Second, the City was entitled to move to market-based rates and it had made that decision for "a legitimate public policy purpose and using a reasonable approach." 286 Such a move was also consistent with government policy to introduce competition at the retail level. Indeed, although the Commission does not quite say it, any other decision would likely have been unlawful. The Commission rejected what seems to have been the Town's main objective, which was to have the City price its gas on the basis of the cost of production rather than its market value. ${ }^{287}$ The Town was unable to claim that the City was engaging in unjust discrimination to the extent that it had chosen to use revenues from the sale of its gas to reduce the municipal tax burden of its own residents but had not extended that benefit to residents of the Town. The Town was not entitled to receive a similar benefit in the form of continued subsidization of the commodity price of gas.

Third, the Commission noted that the City followed a reasonable rate-making process to establish the distribution charges. ${ }^{288}$ It had conducted a cost allocation process, it had established a rate base, it had adopted a capital structure similar to that of regulated gas utilities, and it had adopted an approach to cost of capital drawing on the AUC's generic

PUA, supra note 2, s 81; GUA, supra note 2, s 17.

See e.g. AUC Decision 2010-222, supra note 5 at para 106: "The Commission is called upon to exercise its discretion under section 44(2) of the Municipal Government Act." Ibid at para 59 .

It is not clear why this follows. The Commission clearly has a much broader jurisdiction under section 44 than it has under section 43 in recognition of the fact the municipality receiving the utility service has no political input into the terms of that service (a point that the Commission itself acknowledges). The Commission does not offer a statutory basis for this expectation and thus it is either based on principles of procedural fairness (and judged against that set of standards) or purely hortatory.

AUC Decision 2010-222, supra note 5 at paras 110-16.

Ibid at para 120 .

Ibid at para 121.

Ibid at paras 124-27. 
procedures for establishing an appropriate return on equity and the posted long-term interest rates of the Alberta Capital Finance Authority for the cost of debt. ${ }^{289}$ The Commission concluded:

All in all, the approach used by the City to establish the gas distribution rates to be paid by customers was consistent with Alberta regulatory principles. Even though the results produced by that approach might not have been identical to the results that might have been produced had the AUC or EUB conducted the process, there is no indication that the process or the approach taken could lead to the conclusion that it would be proper for the Commission to upset the results produced by the City's process and approach and order a full Commission-conducted rate case in its place. $^{290}$

Finally, the Commission emphasized that while rate regulation approaches might be appropriate in the case of a monopoly provider of a service, ${ }^{291}$ that was not the case here; the Town had other options available to it. ${ }^{292}$ It could have tried to renegotiate the contract, it could have re-assumed ownership and control of the utility function, and it could have entered into gas supply arrangements on the market. ${ }^{293}$ While not all of these options are completely convincing (for example the Town could not operate as a preferred supplier of gas to its residents), the basic point is perhaps that, in the changed circumstances of an unbundled gas supply chain, the Town was not entitled to insist on an arrangement that ignored these developments. Such a position would not be "proper" within the meaning of section 44 of the MGA. The Commission put the point this way in its concluding paragraphs dealing with the distribution and commodity issues:

\begin{abstract}
Neither the Town nor any of the customers in Redcliff are captive under the Agreement. They are not being forced to accept service under that Agreement and are not being forced to accept the gas commodity rates charged by the City. The Town has other options but has not chosen to pursue them. Instead, it has chosen to seek a remedy from the Commission under the Agreement when the Agreement is only in force because of a section of the legislation that is meant to protect customers during a transitional period in which the parties are to determine future arrangements.
\end{abstract}

In these circumstances, the Commission does not consider that it would be proper to grant the relief sought by the Town. ${ }^{294}$

The Commission dealt separately with the Energy Conservation Charge (ECC) that the City imposed as part of the rate. The rate applied to residential customers using more than 22 GJ per month. The City would expend monies received from the ECC on "renewable and alternative energy, resource conservation, conservation incentives, and education projects and programs to the benefit of all residential customers, both in the City and in the Town."295 While the discussion of this charge is short, the Commission did not interfere, principally on the basis that the ECC was "a rate charged for natural gas service" and customers were 
entitled to access the funds raised by the charge, regardless of whether they were residents of the City or the Town. ${ }^{296}$

The result of the Commission's decision was that the GSA would remain in place (no party having asked the Commission to terminate it). Distribution rates would continue to be set by the City's bylaw as changed from time to time, while the commodity charge would be market based, with the provision that individual consumers would be free to obtain retail service from any competitive retailer operating in that part of the province. In this case, the Commission was convinced that the City was operating the distribution side of the business according to sound rate regulation principles. While the Commission confirmed that it had broad regulatory oversight under section 44 of the $M G A$, it clearly considered that the Town had not established the need for the Commission to intervene. In sum, the Commission found that the City's rates tolls and charges were appropriate.

\section{F. CONCLUSIONS WITH RESPECT TO SECTION 44 DisputeS}

All five of these decisions confirm that the Commission has broad authority to settle disputes between municipalities on terms that it considers "proper." In most, if not all cases, section 44 disputes will entail the interpretation of an existing agreement between the parties; and that agreement may also double as a section 45 franchise agreement. The Commission has made it clear that that which constitutes "proper" settlement terms will vary with the circumstances. In some cases, perhaps most, proper settlement terms will involve application of standard principles of utility regulation, but in other cases, the Commission may conclude that other approaches may be more appropriate or "proper" for the circumstances of the particular case.

One of the puzzles in relation to these decisions is the Commission's conclusion that it can assume jurisdiction for several of these disputes under multiple statutory provisions. This suggests that government should review the interplay of the various utility statutes and the $M G A$ with the goal of avoiding overlapping and duplicative statutory sources for the Commission's jurisdiction. While no harm seems to have come from this overlap (other than delay in the Morinville case as a result of having to re-file at the AUC's direction), all parties would likely benefit from greater clarity as to the application of the Commission's very broad statutory authority under the PUA and the MGA over these types of inter-municipal disputes with respect to the provision of municipal services.

\section{Overall Conclusions}

Utility services, including water, gas, electricity, and sewage are essential to our quality of life, and yet such services (or elements of them) are typically offered by monopoly providers rather than through a competitive market. This makes consumers vulnerable both with respect to price but also with respect to the terms and conditions of service. The typical response is economic regulation with respect to all of the elements of the value chain, or at least those elements that can be characterized as natural monopolies (transmission and distribution). That in turn leads to the question of who should regulate and the scope or 
extent of that regulation. This article has focused on regulation at the municipal level. The provincial legislature in Alberta has largely been content to leave economic regulation at the local level in the situations in which the municipality itself has elected to provide the service. In most such cases (there is an exception for electricity distribution in both Calgary and Edmonton $^{297}$ ), municipal councils are responsible for regulating municipally owned utilities, subject only to an appeal to the AUC on any one of three grounds prescribed in section 43 of the MGA. This article has examined how the Commission has exercised that jurisdiction so as to ensure that the rates established for utility service within a municipality conform to standards established in the bylaws (internal consistency), standards prescribed by provincial law (external consistency), and to ensure that such rates are not unduly or unreasonably discriminatory. The Commission's review is both retrospective and prospective, but it can only provide a remedy to the appellant(s) — although the possibility of further appeals from similarly situated parties should extend the normative significance of AUC decisions beyond the specific instance and provide guidance more generally.

The political calculus with respect to regulatory oversight is different in those situations in which one municipality, in addition to providing service to its own residents, also provides service within the boundaries of another municipality. In such a case, the MGA effectively extends two levels of oversight to protect the interests of the municipality receiving service. First, the initial decision to provide service should require approval of a franchise agreement under section 45 of the MGA. Second, in the event of a dispute as to the terms of service, either party (the providing or receiving municipality) may have to resort to the Commission to have it assess the propriety of the rates, tolls, or charges under section 44 of the MGA. This statutory mandate affords the Commission a broad discretion, informed, but not necessarily controlled by, traditional ideas of rate regulation, in settling such disputes. There are far fewer decisions on section 44 of the MGA than on section 43, but the decisions do confirm that the Commission's jurisdiction under section 44 is much wider than its jurisdiction under section 43, and that the Commission has exercised its jurisdiction in a flexible way to respond to the circumstances of particular cases. 
[this page is intentionally blank] 